\title{
Four New Species in Habenaria (Orchidaceae) from the Espinhaço Range, Brazil
}

Author(s): João A. N. Batista, Aline A. Vale , Bruno M. Carvalho, Karina Proite , Aline J. Ramalho , Ana Cristina D. Munhoz, Cassio van den Berg, and Luciano B. Bianchetti

Source: Systematic Botany, 41(2):275-292.

Published By: The American Society of Plant Taxonomists

URL: http://www.bioone.org/doi/full/10.1600/036364416X691858

BioOne (www.bioone.org) is a nonprofit, online aggregation of core research in the biological, ecological, and environmental sciences. BioOne provides a sustainable online platform for over 170 journals and books published by nonprofit societies, associations, museums, institutions, and presses.

Your use of this PDF, the BioOne Web site, and all posted and associated content indicates your acceptance of BioOne's Terms of Use, available at www.bioone.org/page/terms_of_use.

Usage of BioOne content is strictly limited to personal, educational, and non-commercial use. Commercial inquiries or rights and permissions requests should be directed to the individual publisher as copyright holder. 
Systematic Botany (2016), 41(2): pp. 275-292

(C) Copyright 2016 by the American Society of Plant Taxonomists

DOI 10.1600/036364416X691858

Date of publication June 28, 2016

\title{
Four New Species in Habenaria (Orchidaceae) from the Espinhaço Range, Brazil
}

\author{
João A. N. Batista, ${ }^{1,4}$ Aline A. Vale, ${ }_{1}^{1}$ Bruno M. Carvalho, ${ }^{1}$ Karina Proite, ${ }^{1}$ Aline J. Ramalho, ${ }^{1}$ \\ Ana Cristina D. Munhoz, ${ }^{1}$ Cassio van den Berg, ${ }^{2}$ and Luciano B. Bianchetti ${ }^{3}$ \\ ${ }^{1}$ Universidade Federal de Minas Gerais, Departamento de Botânica, Avenida Antônio Carlos 6627, Pampulha, \\ Caixa Postal 486, 31270-910, Belo Horizonte, Minas Gerais, Brazil \\ ${ }^{2}$ Departamento de Ciências Biológicas, Universidade Estadual de Feira de Santana, Av. Transnordestina s/n, 44036-900, \\ Feira de Santana, Bahia, Brazil \\ ${ }^{3}$ Embrapa Recursos Genéticos e Biotecnologia, Parque Estação Biológica, Final Avenida W5 Norte, Caixa Postal 02372, \\ 70770-901, Brasília, Distrito Federal, Brazil \\ ${ }^{4}$ Author for correspondence (janb@icb.ufmg.br) \\ Communicating Editor: Leslie Goertzen
}

\begin{abstract}
Four new species of Habenaria restricted to the Espinhaço Range in the states of Minas Gerais and Bahia are described: H. reflexicalcar, $\boldsymbol{H}$. hippocrepica, $\boldsymbol{H}$. quadriferricola, and $\boldsymbol{H}$. espinhacensis. Specimens were collected as long ago as 1816 , but they were misidentified or unidentified in herbarium collections. Molecular phylogenetic analyses based on nuclear and plastid DNA sequences showed that these species form a highly supported clade, denominated Espinhacenses, which is related to other species having linear, grass-like leaves that are concentrated in the cerrado and campos rupestres vegetation of central and southeastern Brazil, although the closest relatives to the Espinhacenses clade were not resolved. There are no apparent morphological synapomorphies for the clade, it being characterized by a combination of characters, including slender plants, linear leaves, spiral inflorescences, few to many small and glabrous flowers, a pedicel that is shorter than the ovary, and separate hemipollinaria.
\end{abstract}

Keywords-Campo rupestre, endemism, Minas Gerais, phylogenetic analysis.

Habenaria Willd. (tribe Orchideae, subtribe Habenariinae) is a large genus of terrestrial orchids, currently estimated to comprise $\sim 882$ species (Govaerts et al. 2015). The geographical distribution range of Habenaria includes tropical, subtropical, and temperate regions of the Old and New Worlds (Pridgeon et al. 2001). The Brazilian flora is especially rich in Habenaria species, and accounts for approximately one quarter of all taxa known to the genus (Batista et al. 2011a; Govaerts et al. 2015).

According to the Species List of the Brazilian Flora (Barros et al. 2015), Minas Gerais State in southeastern Brazil has the highest number of Habenaria species (104 species) in the country; this state also has the highest number of vascular plants (12,249 species) and Orchidaceae (945 species) (Lista de Espécies da Flora do Brasil 2015). The Espinhaço Range extends for approximately $1,100 \mathrm{~km}$ in a generally northsouth direction, from central Minas Gerais to northern Bahia State $\left(10^{\circ}-20^{\circ} 35^{\prime} \mathrm{S}\right)$, with elevations above $800 \mathrm{~m}$ and some peaks reaching above 2,000 $\mathrm{m}$ (Rapini et al. 2002). It represents the phytogeographical divisor of three major Brazilian biomes (the Atlantic Forest to the east, and Cerrado and Caatinga to the west) that influence adjacent biotas (Salino and Almeida 2008). In addition to the influence of these different biomes and the interactions of distinct geological characteristics, its isolation and latitudinal and altitudinal extensions, the climate, and fire events all create multiple constraints enabling the coexistence of a large number of species and a remarkable biodiversity which make it one of the most speciesrich areas in the state.

The Espinhaço Range is composed principally of quartzite and sandstone formations covered by acidic and oligotrophic soils that are usually shallow and sandy. Cerrado (neotropical savanna) vegetation and gallery forests are found there, but it is largely dominated by campos rupestres (rocky fields), an open vegetation form that usually appears at elevations above $900 \mathrm{~m}$ and is composed mainly of herbaceous and sclerophyllous evergreen shrubs or subshrubs (Rapini et al. 2002). Some authors consider these campos rupestres areas as "vegetation refuges," or "vegetation relics," as they are isolated and embedded in completely distinct contexts within the dominant floras of the regions (Vasconcelos 2011). Campos rupestres also occur as isolated floristic islands in Goiás State, the Federal District, in the southwestern and southern regions of Minas Gerais State, in Roraima State, in the Chapada dos Parecis in Rondônia State, and Serra do Cachimbo in Pará State (Giulietti and Pirani 1988; Rapini et al. 2008; Dutra et al. 2008), and it is in these fields, especially those of the Espinhaço Range, where much of the Brazilian endemic biodiversity is found. Plant diversity and the numbers of endemic species of these campos rupestres are particularly notable for families such as Eriocaulaceae, Velloziaceae, and Xyridaceae (Giulietti and Pirani 1988; Echternacht et al. 2011). As for species distribution patterns within the Espinhaço Range, some occur throughout its extent while others have more limited distributions, with only a small proportion of them being common to both Minas Gerais and Bahia (Rapini et al. 2008). The floristic similarities between areas (Azevedo and van den Berg 2007) or within specific areas (Conceição and Pirani 2007) of the range are often surprisingly low.

Some plant families (and other groups) have been the focus of floristic inventories in the Espinhaço Range, including ferns (Salino and Almeida 2008), Bromeliaceae (Versieux and Wendt 2007; Versieux et al. 2008), Apocynaceae (Rapini et al. 2002), and Eriocaulaceae (Costa et al. 2008), however there are no published inventories of the Orchidaceae or the genus Habenaria of the Espinhaço Range as a whole. Local inventories of Orchidaceae (Barros 1987; Toscano-de-Brito 1995; Zappi et al. 2003; Barros and Pinheiro 2004; Mota 2006; Munhoz 2007) and descriptions of some new species of Habenaria from this range (Batista and Bianchetti 2006; Batista et al. 2008a, 2008b), however, indicate a high diversity of the genus there. We describe here four new species of Habenaria from the Espinhaço Range based on field collections and examinations of herbarium collections, and investigate 
their phylogenetic affinities using nuclear (ITS) and plastid (matK) markers.

\section{Materials AND Methods}

Taxon Sampling for Phylogenetic Analyses - The datasets for the phylogenetic analyses consisted of the combined ITS and partial matK DNA sequences of 203 terminals of approximately 140 Neotropical Habenaria taxa (corresponding to $47 \%$ of the total number of species known from the Neotropical region; Batista et al. 2011a, 2011b) and four African Habenaria species; Gennaria diphylla Parl. was used as the functional outgroup. This dataset is basically the same as that used by Batista et al. (2013) to infer the phylogenetic relationships of the New World Habenaria, although it includes the new species described here and excludes most of the Old World taxa. Morphological and geographical variants of $H$. hippocrepica and H. espinhacensis were sampled to analyse intraspecific relationships. Voucher information, geographic origins, and GenBank accession numbers can be found in Batista et al. (2013); information concerning the newly sequenced accessions is provided in Appendix 1.

Molecular Markers - Nucleotide sequences from one nuclear (ITS) and one plastid $(m a t K)$ genome regions were analyzed. The ITS region consisted of the $3^{\prime}$ and $5^{\prime}$ ends of the $18 \mathrm{~S}$ and 26S ribosomal RNA genes, respectively, internal transcribed spacers (ITS1 and ITS2), and the intervening $5.8 \mathrm{~S}$ gene of the nuclear ribosomal multigene family. Amplifications of these regions were performed using 17SE and 26SE as primers (Sun et al. 1994). For the matK gene, we used an internal fragment of approximately $630 \mathrm{bp}$, amplified with matK-F2 and matK-R2 primers (Batista et al. 2013), which approximately corresponds to the region widely used for barcoding land plants (Chase et al. 2007). This fragment is the most variable region of the gene in several orchid groups (e.g. Whitten et al. 2000). DNA extraction, amplification, and sequencing were carried out following standard protocols, as described by Batista et al. (2013). Bidirectional sequence reads were obtained for all of the DNA regions, and the resulting sequences were edited and assembled using Staden Package software (Bonfield et al. 1995). The edited sequences were aligned with MUSCLE (Edgar 2004), and the resulting alignments were manually adjusted using MEGA4 software (Tamura et al. 2007). The data were submitted to the Dryad Digital Repository (http://datadryad.org/; http://dx.doi.org/10.5061/ dryad.f39q8)

Phylogenetic Analyses - The data were analyzed using parsimony and Bayesian inference. Searches were performed only with a combined matrix, as no cases of strongly supported incongruence were detected in our previous analyses with the same datasets (Batista et al. 2013). Phylogenetic analyses using maximum parsimony (MP) were performed using PAUP* version 4 (Swofford 2002) with Fitch parsimony (equal weights, unordered characters; Fitch 1971) as the optimality criterion. Each search consisted of 1,000 replicates of random taxon additions, with branch swapping using the tree-bisection and reconnection (TBR) algorithm, saving $\leq 10$ trees per replicate to avoid extensive swapping on suboptimal islands. Internal support was evaluated by character bootstrapping (Felsenstein 1985) using 1,000 replicates, simple addition, and TBR branch swapping, saving $\leq 10$ trees per replicate. For bootstrap support levels, we considered bootstrap percentages (BS) of $50-70 \%$ as weak, $71-85 \%$ as moderate, and $>85 \%$ as strong (Kress et al. 2002).

Bayesian analysis was conducted using MrBayes v. 3.1.2 (Ronquist et al. 2005) as implemented in the Cyberinfrastructure for Phylogenetic Research (CIPRES) Portal 2.0 (Miller et al. 2010), treating each DNA region as a separate partition. An evolutionary model for each DNA region was selected using the Akaike information criterion (AIC) in MrModeltest 2 (Nylander 2004), and the GTR + I + G model was selected for both data sets. The unlink command was used to unlink parameters among each partition. Each analysis consisted of two independent runs, each with four chains, for 15,000,000 generations, sampling one tree every 1,000 generations. To improve chain swapping, the temperature parameter for heating the chains was lowered to 0.1 in the combined analysis. Convergence between the runs was evaluated using the average standard deviation of split frequencies $(<0.01)$, and was achieved after 1,635,500 generations. After discarding the first 5,000 trees $(33 \%)$ as the burn-in, the remaining trees were used to assess topology and posterior probabilities (PP) in a majority-rule consensus. Posterior probabilities (PP) in Bayesian analysis are not directly comparable to bootstrap percentages, being generally much higher (Erixon et al. 2003). We therefore used criteria similar to a standard statistical test, considering groups with PP $>0.95$ as strongly supported, groups with PP ranging from $0.90-0.95$ as moderately supported, and groups with PP $<0.90$ as weakly supported.

Morphological and Taxonomic Analyses-Descriptions were based on liquid-preserved or dry herbarium material. The habit and perianth were examined and drawn from liquid-preserved or dried herbarium material, while the gynostemium was examined from liquid-preserved material, using a stereoscopic microscope, and measured using a digital caliper. Data concerning flowering times, habitat, and distribution were based on herbarium labels and field observations. Descriptive terminology is based on Stearn (1992) and Simpson (2006). Materials were searched in 69 herbaria in Brazil, Europe, and the United States and were found and examined from the following: BHCB, CEN, ESA, HB, HBG, HUEFS, K, MBM, NY, P, RB, SP, SPF, UEC, and UB; acronyms following Thiers (2015).

\section{Results AND Discussion}

Phylogenetic Analyses-The combined ITS and partial matK gene matrix consisted of 1,371 aligned characters, of which 306 (22\%) were parsimony-informative. The parsimony analyses retained a total of 4,890 most parsimonious trees, with a tree length of 944 steps, a consistency index (CI) of 0.64 , and a retention index (RI) of 0.85 . The strict consensus was for the most part congruent with the Bayesian majorityrule consensus tree, but as the latter was more fully resolved and had stronger overall support, it was chosen for presentation here (Fig. 1). For comparison, the strict consensus tree from the parsimony analyses is presented as supplemental material (Figs. S1a, b). The relationships recovered were similar to those of our earlier molecular phylogenetic study (Batista et al. 2013), with the New World Habenaria species forming a well-supported monophyletic group (1.00 PP, 88\% BS, Fig. 1) that was sister to the African species H. tridens Lindl. (1.00 PP, 100\% BS). Several well-supported subclades were recovered within the New World clade (Fig. 1) that corresponded to the same subclades identified in our previous analyses (Batista et al. 2013), and are numbered accordingly (subclades 1-21). The newly described species formed a strongly supported clade in the Bayesian analysis (1.00 PP, $63 \%$ BS) denominated here Espinhacenses, as all of the species in the clade are restricted to the Espinhaço Range. The Espinhacenses clade was placed in a well-supported clade (1.00 PP, 67\% BS) formed by subclades 16-21. Most of the species in these subgroups have linear, grass-like leaves that are commonly adpressed to the stem, are primarily Brazilian, and are mostly concentrated in the cerrado and campos rupestres vegetation in the central and southeastern regions of Brazil (Batista et al. 2013). The closest relatives to the Espinhacenses clade were not resolved. The clade was moderately supported (0.95 PP) as sister to subclade 19 (formed by H. urbaniana Cogn. and H. fluminensis Hoehne); however, bootstrap support was low $(<50 \% \mathrm{BS})$, and there are no apparent morphological similarities between the Espinhacenses clade and those species, as $H$. urbaniana and $H$. fluminensis are robust plants (stem $43-116 \mathrm{~cm}$ long, including the inflorescence, 2.2-6.0 mm wide), with lanceolate leaves (6.5-24 $\times$ $(0.5-) 1.1-1.9(-2.7) \mathrm{cm}$ ), and large flowers (pedicellate ovary 23-31 mm long; dorsal sepal 11.4-18.0 × 7.5-14.0 mm). Relationships with other species, such as $H$. aff. subfiliformis Cogn., H. pseudoculicina J. A. N. Bat. \& B. M. Carvalho, and H. aff. canastrensis J. A. N. Bat. \& B. M. Carvalho had no support (0.94 PP, <50\% BS).

The internal relationships of the Espinhacenses clade were not resolved. In the Bayesian analysis, specimens of $H$. espinhacensis from the northern range of the species (Grão Mogol, Serra 


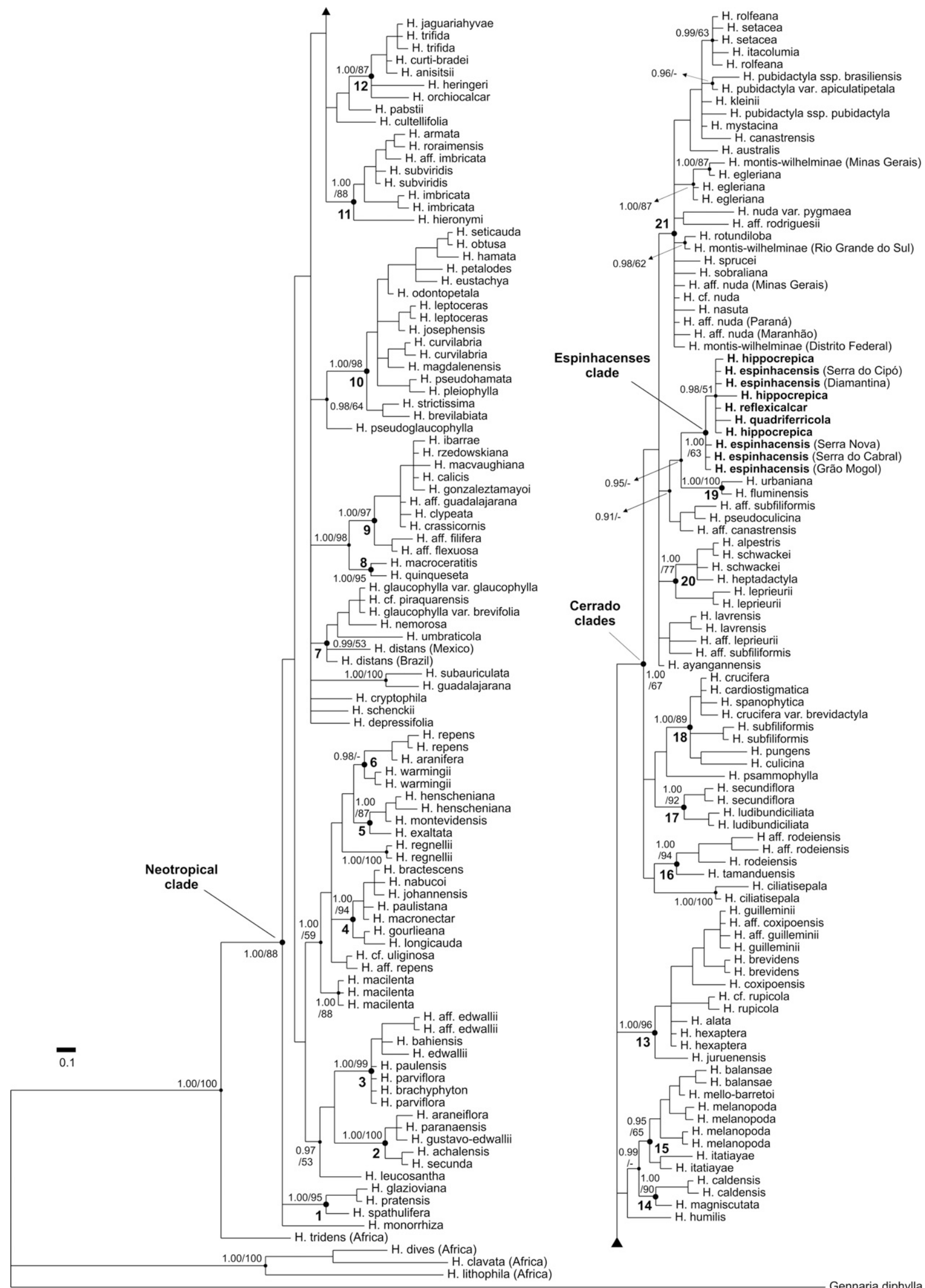

Fig. 1. Bayesian majority-rule consensus tree of the combined ITS and matK datasets. Numbers next to the nodes represent the posterior probabilities and bootstrap percentages (PP/BS). Only values of major clades and posterior probabilities $\geq 0.95$ are shown. Bootstrap percentages $\leq 50 \%$ are indicated by a dash (-). Neotropical subgroups are numbered according to Batista et al. (2013). The generic name for all Habenaria species is abbreviated. The new species described here are highlighted in bold. 
do Cabral, Serra Nova) formed a polytomy with a subclade (0.98 PP) of specimens from the southern range of the species (Serra do Cipó, Diamantina) plus the remaining species of the clade $(H$. reflexicalcar, $H$. hippocrepica, $H$. quadriferricola), although support for this topology was low in the parsimony analysis (51\% BS). In this context, a disjunction between the Orchidaceae composition of the southern and central portions of the Espinhaço Range in Minas Gerais from its northern section in Minas Gerais and Bahia has been described by Azevedo and van den Berg (2007). Additional studies, such as a haplotype analysis, are necessary to verify our results and permit further insights into this question. Habenaria hippocrepica and $H$. espinhacensis, represented by more than one sample each, were not recovered as monophyletic. However, this result is explained by the low internal resolution of the clade and low sequence divergence among the Neotropical taxa of Habenaria (Batista et al. 2013), indicating that ITS and matK sequences alone are not sufficient to separate closely related species of Neotropical Habenaria.

\section{TAXonomic Treatment}

Morphological characterization of the Espinhacenses clade-Plants small to medium sized, slender, 9-53(-68) cm, including the inflorescence. Leaves linear, narrowly-lanceolate or filiform, sheathing to patent, amplexicaul. Inflorescence spiral, few to many flowered, lax to congest, (0.7-)0.9-3.5(-5.0) flowers/cm inflorescence. Flowers 2-35(-48), small, glabrous, completely green; pedicel shorter than the ovary. Dorsal sepal 2.5-6.0 × 2.0-5.0 mm. Petals bipartite. Lip tripartite. Spur 4$12 \mathrm{~mm}$ long. Stigma lobes $1.2-2.0 \mathrm{~mm}$ long, closely parallel. Hemipollinaria separate.

Notes - This clade consists of a small group of four species restricted to the Espinhaço Range, mostly in the state of Minas Gerais. Growing in seasonally wet grasslands (campo limpo estacionalmente úmido) frequently associated with rock outcrops in campo rupestre vegetation, from $600-1,900 \mathrm{~m}$. Flowering occurs during the rainy season, from November to March (Table 1), in southeastern Brazil. Most are common throughout each distribution range, sometimes forming large populations.

\section{Key to the Species of Habenaria in the Espinhacenses Clade}

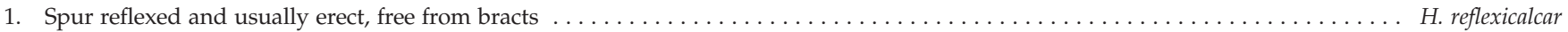

1. Spur deflexed, parallel to the pedicellate ovary, usually enclosed by bracts $\ldots \ldots \ldots \ldots$

2. Lateral sepals conspicuously aristate, arista $0.4-0.9 \mathrm{~mm}$ long; anterior petal segment $1.0-2.0 \mathrm{~mm}$ long, 0.2-0.4 times as long as posterior segment; lateral lip segments $1.8-4.0 \mathrm{~mm}$ long, $0.4-0.6(-0.9)$ times as long as median segment;

species restricted to the high altitude fields of Quadrilatero Ferrífero $\ldots \ldots \ldots \ldots \ldots \ldots$ quadriferricola

2. Lateral sepals usually not aristate, or inconspicuously aristate, arista 0.0-0.6 mm long; anterior petal segment 3.6-12.0 mm long, 0.9-2.0 times as long as posterior segment; lateral lip segments 4-11 mm long,

1.0-1.7 times as long as median segment; species distributed throughout the Espinhaço Range except in Quadrilatero Ferrífero . . . . . . . . . . 3

3. Inflorescence usually congested, (1.0-)1.5-3.5(-5.0) flowers per cm of inflorescence; pedicellate ovary 6.0-10.5 mm long; spur 4.1-6.8 mm long; anterior petal segment (0.9-)1.1-1.3(-1.5) times as long as posterior segment; connective 1.4-2.3 mm long; rostellum mid-lobe apex rounded, side-lobes slightly convergent towards the apex ... . . H. hippocrepica

3. Inflorescence lax, (0.7-)0.9-1.4(-1.8) flowers per cm of inflorescence; pedicellate ovary (8-)11-14 mm long; spur 7-12 mm long; anterior petal segment (1.2-)1.5-2 times as long as posterior segment;

connective $0.5-0.9 \mathrm{~mm}$ long; rostellum mid-lobe apex acute to subacute, side-lobes parallel throughout ................ H. espinhacensis

Habenaria reflexicalcar J. A. N. Bat. \& B. M. Carvalho, sp. nov.-TYPE: BRAZIL. Minas Gerais: Santana do Riacho, Serra do Cipó, MG-010, cerca de $36.6 \mathrm{~km}$ após a ponte sobre o córrego Soberbo em Cardeal Mota, em direção a Conceição do Mato Dentro, morro com uma cruz, entrada para a parte de cima da Cachoeira do Tabuleiro, $19^{\circ} 09^{\prime}$ 26.4"S, 4331'08.8”W, 1,357 m, 10 Dec 2006 (fl), J. A. N. Batista, R. C. Mota \& H. R. El Bizri 1744 (holotype: BHCB; isotypes: CEN, HUEFS, MBM, RB, SP).

Similar in overall morphology to other species with slender plants, linear leaves, small flowers, and petals and lip with long lateral segments, such as $H$. ayangannensis Renz, $H$. canastrensis, $H$. ludibundiciliata J. A. N. Bat. \& Bianch., H. psammophila J. A. N. Bat., Bianch. \& B. M. Carvalho, H. pseudoculicina, and other species described here, but distinct from all by the reflexed and usually erect spur. It is similar in this character to H. cryptophila Barb. Rodr. and H. armata Rchb.f., but distinct from both by being slender plants with linear leaves.

Terrestrial slender, caulescent herb. Tuberoid ellipsoid, $8 \times$ $6 \mathrm{~mm}$. Roots few, $1 \mathrm{~mm}$ wide. Stem erect, 11-33(-48) cm, including the inflorescence, $0.5-1.3(-1.6) \mathrm{mm}$ wide. Leaves 3-6, base sheathing, sheath closed, blade partially adpressed to the stem or ascending, linear to narrowly lanceolate, largest at center of the stem, (1.5-)3.0-5.5(-9.5) × 0.15-0.35(-0.5) cm, membranaceous, acuminate. Inflorescence $2-15 \mathrm{~cm}$, lax, spiral, 1.3-2.0(-2.4) flowers for $\mathrm{cm}$ of inflorescence; bracts ovate to ovate-lanceolate, shorter than the pedicellate ovary, 3.5-8.0 $\times$ 2.5-3.6 mm, acuminate. Flowers 2-22(-28), resupinate, glabrous, mostly green; pedicellate ovary ascending, 6-10 mm long; ovary slightly to strongly arched, 5.5-7.5 $\mathrm{mm}$ long, pedicel $1.5-3.0 \mathrm{~mm}$ long. Sepals green, margins whitish, arista

TABLE 1. Number of collections of Habenaria species of the Espinhacenses clade by month of the year. The rainy and dry season periods presented here are in reference to central and southeastern Brazil.

\begin{tabular}{|c|c|c|c|c|c|c|c|c|c|c|c|c|c|}
\hline \multirow[b]{2}{*}{ Taxa } & \multicolumn{7}{|c|}{ Rainy season } & \multicolumn{5}{|c|}{ Dry season } & \multirow[b]{2}{*}{ Total } \\
\hline & Oct & Nov & Dec & Jan & $\mathrm{Feb}$ & Mar & Apr & May & Jun & Jul & Aug & Sep & \\
\hline H. reflexicalcar & & 5 & 20 & 4 & 6 & & & & & & & & 35 \\
\hline H. hippocrepica & & 1 & 0 & 4 & 28 & 16 & 5 & & & & & & 54 \\
\hline H. quadriferricola & & & & 1 & 7 & 5 & & & & & & & 13 \\
\hline H. espinhacensis & & & & 5 & 6 & 6 & & & & 1 & & & 18 \\
\hline
\end{tabular}


absent or inconspicuous, $0.0-0.3 \mathrm{~mm}$ long; dorsal sepal concave, ovate to roundish when flattened, 2.5-4.2 × 2.1-3.3 mm; lateral sepals obliquely ovate to ovate-lanceolate, reflexed, 2.8-4.8 × 1.4-2.5 mm. Petals bipartite, light green, base whitish; posterior segment linear-lanceolate, falcate, 2.7-5.1 × 0.5$1.0 \mathrm{~mm}$, adherent or partially free from the dorsal sepal, acute; anterior segment erect, filiform, inserted at the base of the posterior segment at a $90^{\circ}$ angle, 4.1-9.0 mm, (1.1-)1.4$1.9(-2.1)$ times as long as the posterior segment. Lip tripartite, light green, base whitish; undivided basal part short, $0.6-1.9 \times$ 0.7-2.0 mm; lateral segments pendent, apex reflexed, linearfiliform, $4.8-8.5 \times 0.2-0.35 \mathrm{~mm}, 0.8-1.8(-2.0)$ times as long as the median segment; median segment linear, straight, 3.2$5.4 \times 0.3-0.65 \mathrm{~mm}$; spur reflexed, erect, free from the bracts, linear to slightly clavate, shorter than the pedicellate ovary, 4.7-9.1 × 0.5-0.8 mm, green. Gynostemium erect, $1.3-1.5 \mathrm{~mm}$ high; connective emarginate, short, $0.6-0.8 \mathrm{~mm}$ long between the anther loculi, greenish; lateral appendages (auricles) fleshy, verrucose, whitish, $0.45-0.8 \times 0.25-0.7 \mathrm{~mm}$. Anther bilocular, loculi parallel, $0.75-1.1 \mathrm{~mm}$ high, canals $0.6 \mathrm{~mm}$ long; hemipollinaria separate; viscidia $0.15 \times 0.15 \mathrm{~mm}$, spaced $0.7 \mathrm{~mm}$ from each other; caudicles $0.65 \mathrm{~mm}$ long. Stigmatophores (stigma lobes) 2, mostly separate, in contact only at the apices, narrowly oblong, 1.6-1.9 $\mathrm{mm}$ long, whitish, receptive surface flat, turned frontwards, apex $0.25-0.4 \mathrm{~mm}$ wide, obtuse. Rostellum 1.2-1.5 mm long, whitish; mid-lobe erect, triangular, fleshy, obtuse, completely placed between the anther loci, $0.7-0.8 \mathrm{~mm}$ long, $0.8 \mathrm{~mm}$ high; side-lobes parallel to slightly convergent, $0.6 \mathrm{~mm}$ long.

Distribution-Restricted to the central region of the Espinhaço Range in Minas Gerais, from Serra do Cipó to the Diamantina plateau.

Habitat, Ecology, and Phenology-Habenaria reflexicalcar occurs at 1,200-1,400 m a. s. 1., growing in seasonally wet grasslands (campo limpo estacionalmente úmido) on dark, sandy-clayey soils, and is frequently associated with rock outcrops in campo rupestre vegetation. Flowering occurs from November to February, but is concentrated in December, at the beginning of the rainy season (Table 1). Most collections of this species made by the authors were in areas that had been recently burned; as with most other Habenaria and terrestrial orchids from open grasslands (Jones 1993), the flowering of this species is greatly enhanced by brushfires during the dry season. Other Habenaria and orchid species such as H. pubidactyla J. A. N. Bat. \& Bianch. subsp. pubidactyla, H. guilleminii Rchb.f., Gomesa fuscans (Rchb.f.) M. W. Chase \& N. H. Williams, Zygopetalum sellowii Rchb.f., and Cleistes exilis Hoehne grow sympatrically and flower at approximately the same time.

Etymology-From the Latin reflexus (reflexed) and calcar (spur), referring to the reflexed spur of the species.

Conservation Status-According to the World Conservation Union Red List Categories and Criteria (IUCN 2001), this new species can be tentatively classified as of least concern (LC). The species is common throughout its distribution range, sometimes forming large populations, some of which occur within federal or state protected areas.

Notes - H. reflexicalcar was apparently first collected by M. Sazima at Serra do Cipó in 1971. The collection Hatschbach et al. 29060, located in the MBM Herbarium, was identified as H. cf. subfiliformis by G. F. J. Pabst in 1972, but other collections of this species remained indeterminate in several herbaria.
A distinctive feature of $H$. reflexicalcar is its reflexed and usually erect spur (Figs. 2, 3A-B). This characteristic is uncommon among Brazilian species of the genus, and is found in just two other species in that country: $H$. cryptophila and $H$. armata. Both of these species are distinct from $H$. reflexicalcar in several other aspects, however: $H$. cryptophila is a stout plant with leaves large, oblong to lanceolate, and broader $(8.0-27.0 \times 1.8$ $6.0 \mathrm{~cm}$ ), larger flowers (pedicellate ovary 18-26 mm long; spur 22-28 mm long; dorsal sepal 6.0-7.0 × 5.0-6.5 mm), inhabits forests, and is widespread in southeastern, central, and northeastern Brazil, the Andes (Bolivia, Peru), and from northern South America (Colombia, Venezuela, Ecuador) to Costa Rica (Batista et al. 2011a). Habenaria armata has leaves elliptic to oblong, broader $(5.5-8.5 \times 1.0-2.5 \mathrm{~cm})$, inhabits dry savannas, and has a wider geographical distribution, occurring from Paraná State in southern Brazil to Colombia and Venezuela. Furthermore, the direction of the spur is variable in H. armata, with reflexed and erect spurs apparently being found only in some populations in central Brazil; elsewhere the spur is deflexed. A few Mexican and Mesoamerican species such as $H$. crassicornis Lindl. and H. matudae Salazar also have erect and reflexed spurs, although they are very distinct by their elliptic to lanceolate leaves, larger flowers, papillose ovaries and perianths, gynostemium morphologies, habitats, and distributions.

In general, the morphologies of the vegetative and reproductive parts of $H$. reflexicalcar are similar to other species (such as $H$. ayangannensis, $H$. canastrensis, H. ludibundiciliata, H. psammophila, and H. pseudoculicina), being characterized by slender plants, linear leaves, small flowers, and petals and lip with long lateral segments. Besides the positioning of the spur, $H$. reflexicalcar differs from most of these species by having deflexed lateral lip segments, vs. erect or perpendicular to the median segment in $H$. ayangannensis, H. canastrensis, H. psammophila, and H. pseudoculicina. Habenaria ludibundiciliata, which also has deflexed lateral lip segments, is distinct by its conspicuous sepal arista (1.0-1.5(2.0) mm, vs. $0-0.3 \mathrm{~mm}$ in H. reflexicalcar). Habenaria subfiliformis is distinct from $H$. reflexicalcar by its flowers being more distantly spaced on the inflorescence (0.9-1.5 flowers per cm vs. 1.3$2.0(-2.4)$ flowers per $\mathrm{cm}$ in $H$. reflexicalcar), the shorter anterior segments of its petals $(2.3-4.0 \mathrm{~mm}$ vs. $4.1-9.0 \mathrm{~mm}$ in $H$. reflexicalcar), and shorter lateral segments of the lip (3.4$4.4 \mathrm{~mm}$ vs. $4.8-8.5 \mathrm{~mm}$ in $H$. reflexicalcar).

In terms of its floral morphology, $H$. reflexicalcar is also similar to $H$. arachnoides Thouars (specimen Gautier et al. LG 3518 in herbarium G) from Madagascar, including their reflexed and erect spurs. This similarity is remarkable considering the geographic distance that separates them and the fact that neotropical Habenaria are monophyletic (Batista et al. 2013). However, the leaves of $H$. arachnoides are patent and wider (largest leaves about 8.5-9.0 × 1.4-1.5 cm).

In the single specimen of the collection Batista $\mathcal{E}$ Mota $1466 a$ (CEN), the anterior segments of the petals were absent or reduced to tooth-like projections approximately $0.3 \mathrm{~mm}$ long. This was clearly an abnormality, however, as all of the other specimens of the species examined had anterior segments longer than the posterior segment, ranging from 4.1$9.0 \mathrm{~mm}$ long; measurements from this specimen were not included in the description of the species.

Additional Specimens Examined-BRAZIL. Minas Gerais: Santana do Riacho, Serra do Cipó, km 109 estrada Lagoa Santa/Conceição do Mato Dentro, 1,200 m, 1 Feb 1987 (fl), F. de Barros 1313 (SP); Serra do Cipó, 


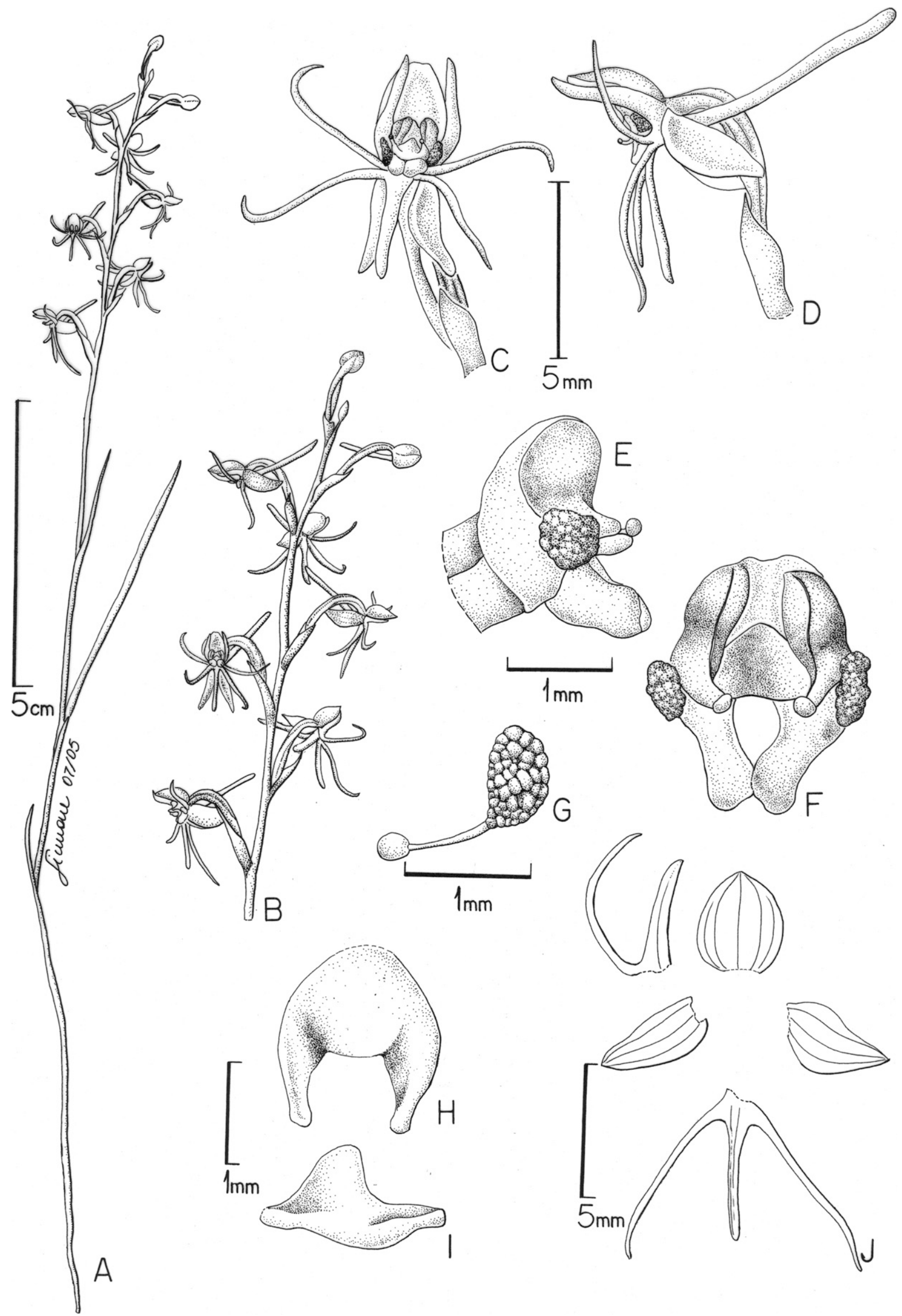

Fig. 2. Habenaria reflexicalcar. A. Habit. B. Inflorescence. C. Flower, front view. D. Flower, lateral view. E. Gynostemium, lateral view. F. Gynostemium, front view. G. Hemipollinarium. H. Rostellum, upper view. I. Rostellum, lateral view. J. Dissected perianth. All based on Batista \& Proite 1005. Drawn by Simone C. Souza e Silva. 


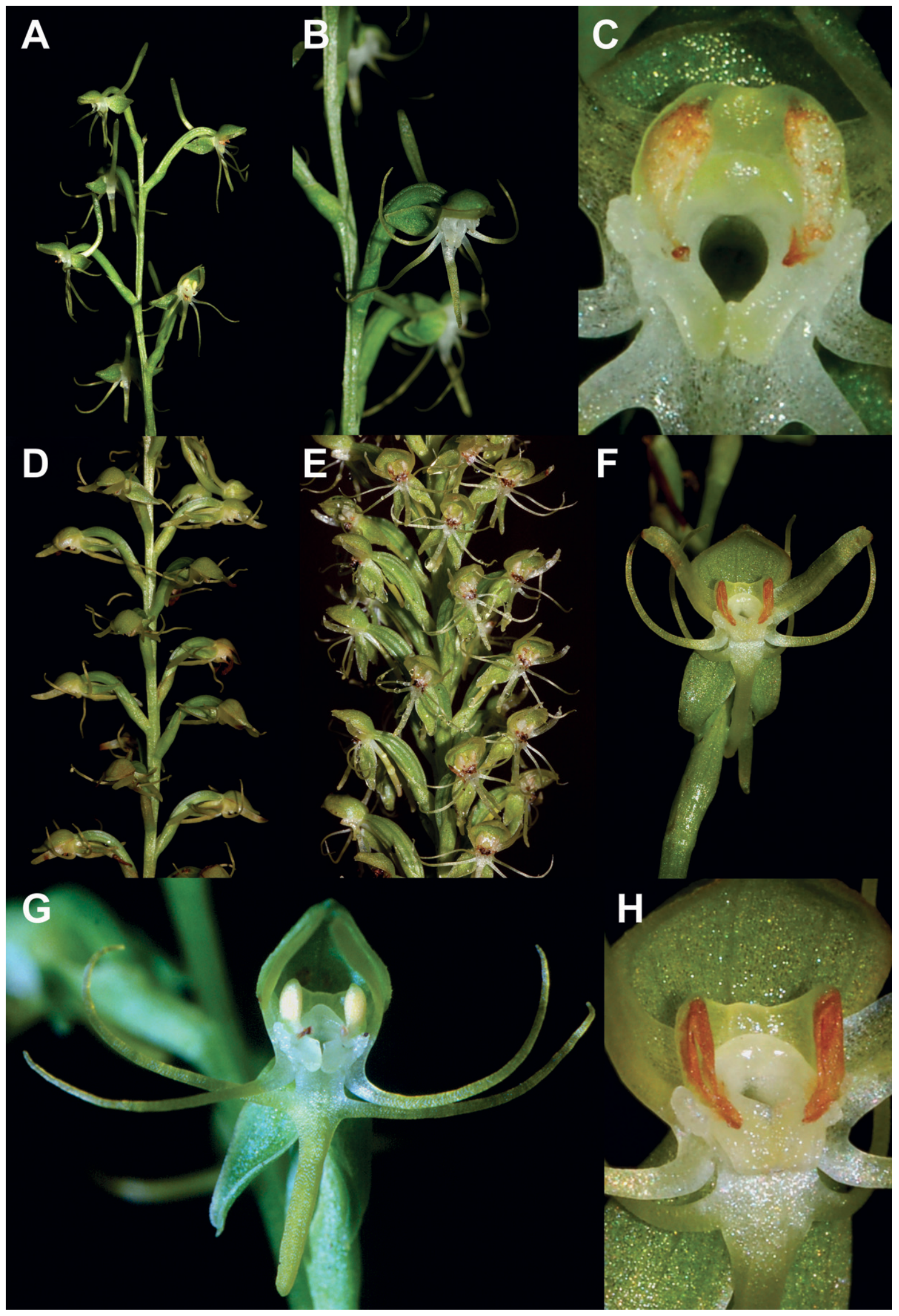

FIG. 3. Habenaria reflexicalcar. A. Inflorescence. B. Flower. C. Gynostemium. Habenaria hippocrepica. D-E. Inflorescence. F-G. Flower. H. Gynostemium. A-C from Batista et al. 1744; D, F and H from Batista et al. 1948 (Diamantina); E from Batista et al. 1920 (Presidente Kubitscheck); G from Batista \& Bianchetti 899. All photographs by João A. N. Batista. 
km 112 na estrada para Conceição do Mato Dentro (MG-10), cerca de $11 \mathrm{~km}$ a NE de Cardeal Mota, 9 Jan 2000 (fl), J. A. N. Batista \& K. Proite 993 (CEN); Serra do Cipó, km 127 na estrada para Conceição do Mato Dentro (MG-10), cerca de 26 km a NE de Cardeal Mota, 9 Jan 2000 (fl), J. A. N. Batista E K. Proite 1005 (CEN); Diamantina, cerca de 20-21 km do entroncamento com a BR-367, $\mathrm{km} \mathrm{171,} \mathrm{em} \mathrm{direção} \mathrm{a} \mathrm{Conselheiro}$ Mata, 12 Jan 2000 (fl), J. A. N. Batista \& K. Proite 1017 (CEN); Santana do Riacho, Serra do Cipó, Km 126 da rodovia Lagoa Santa/Conceição do Mato Dentro, cerca de 26 km após Cardeal Mota, 17 Dec 2003 (fl), J. A. N. Batista E R. C. Mota 1466 (CEN), J. A. N. Batista E R. C. Mota $1466 a$ (CEN); região limítrofe entre os municípios de Santana do Riacho e Conceição do Mato Dentro, Serra do Cipó, Km 136 da rodovia Lagoa Santa/Conceição do Mato Dentro, cerca de $36 \mathrm{~km}$ após Cardeal Mota, 17 Dec 2003 (fl), J. A. N. Batista E R. C. Mota 1467 (BHCB, CEN); Santana do Riacho, Serra do Cipó, cerca de 10-11 km após a ponte sobre o córrego Soberbo em Cardeal Mota, MG-010, 19¹7'6.9' $\mathrm{S}, 43^{\circ} 34^{\prime}$ 29"W, 1,222 m, 10 Dec 2006 (fl), J. A. N. Batista et al. 1734 (BHCB); Santana do Riacho, Serra do Cipó, cerca de $29.3 \mathrm{~km}$ após a ponte sobre o córrego Soberbo em Cardeal Mota em direção a Conceição do Mato Dentro, entroncamento para Morro do Pilar, $19^{\circ} 13^{\prime} 9^{\prime \prime} \mathrm{S}, 43^{\circ} 29^{\prime} 56.7^{\prime \prime} \mathrm{W}$, 1,330 m, 11 Dec 2006 (fl), J. A. N. Batista et al. 1766 (BHCB); Conceição do Mato Dentro, Parque Municipal Ribeirão do Campo, campos no platô da cachoeira do Tabuleiro, $19^{\circ} 05^{\prime} 8.5^{\prime \prime} \mathrm{S}, 43^{\circ} 34^{\prime} 33.4^{\prime \prime} \mathrm{W}, 1,318 \mathrm{~m}$, 13 Dec 2007 (fl), J. A. N. Batista et al. 1773 (BHCB); Santana do Riacho, Serra do Cipó, antigo km 112, $19^{\circ} 19^{\prime} 5.3^{\prime \prime} \mathrm{S}, 43^{\circ} 32^{\prime} 35.5^{\prime \prime} \mathrm{W}, 1,294 \mathrm{~m}$, 14 Dec 2007 (fl), J. A. N. Batista et al. 1782 (BHCB); Santana do Riacho, Parque Nacional da Serra do Cipó, entorno da casa do parque no alto da serra, 19²15'S, 433' W, 1,355 m, 14 Dec 2008 (fl), J. A. N. Batista 2714 (BHCB); Minas Gerais, Diamantina, MG-220, sentido Diamantina para Conselheiro Mata, cerca de 20-21 km do entroncamento com a BR-367, $18^{\circ} 17^{\prime} 44.4^{\prime \prime} \mathrm{S}, 43^{\circ} 50^{\prime} 37.5^{\prime \prime} \mathrm{W}, 1,233 \mathrm{~m}, 6 \mathrm{Jan} 2011$ (fl), J. A. N. Batista et al. 3138 (BHCB); Santana do Riacho, Serra do Cipó, Parque Nacional da Serra do Cipó, região do Alto do Palácio, próximo ao alojamento do IBAMA, 30 Nov 2008 (fl), K. S. Borges 2 (BHCB); Santana do Riacho, Serra do Cipó, Parque Nacional da Serra do Cipó, região do Alto do Palácio, 15 Dec 2009 (fl), K. S. Borges 15 (BHCB), K. S. Borges 18 (BHCB); Santana do Riacho, Serra do Cipó, km 127 rodovia Belo Horizonte/Conceição do Mato Dentro, junto a casa do IBDF, 13 Dec 1985 (fl), N. S. Chukr et al. in CFSC 9450 (SPF); Diamantina, Guinda, 20 Feb 1972 (fl), G. Hatschbach et al. 29060 (MBM); Conceição do Mato Dentro, BR-010, Serra do Espinhaço, 12 Nov 1997 (fl), G. Hatschbach et al. 67447 (HBG, MBM); Jaboticatubas, Serra do Cipó, km 142 rodovia Lagoa Santa-Conceição do Mato Dentro, 3 Nov 1972 (fl), A. B. Joly E J. Semir 3641 (SP); Santana do Riacho, MG-010, Estrada para Conceição do Mato Dentro, km 138, 18 Dec 2006 (fl), F. Marino et al. 206 (BHCB); Conceição do Mato Dentro, Parque Natural Municipal do Ribeirão do Campo, 8 Nov 2002 (fl), R. C. Mota E P. L. Viana 1696 (BHCB); Conceição do Mato Dentro, Parque Natural Municipal do Ribeirão do Campo, região da nascente do Ribeirão do Campo, 24 Dec 2002 (fl), R. C. Mota 1697 (BHCB, CEN); Santana do Riacho, Serra do Cipó, $12 \mathrm{~km}$ após o Córrego Soberbo em Cardeal Mota (antigo km 112) em direção à Conceição do Mato Dentro, 19²17'S, 43³3'W, 1,258 m, 19 Dec 2007 (fl), A. C. D. Munhoz et al. 63 (BHCB); Santana do Riacho, Serra do Cipó, márgem do Córrego Três pontinhas, $19^{\circ} 17^{\prime} 20^{\prime \prime} \mathrm{S}, 43^{\circ} 33^{\prime} 41^{\prime \prime} \mathrm{W}$, 1,194 m, 13 Feb 2008 (fl), A. C. D. Munhoz \& C. A. N. Martins 113 (BHCB); Congonhas do Norte, Serra Talhada, setor nordeste da Serra do Cipó, $6 \mathrm{~km}$ SW da estrada Congonhas do Norte - Gouveia, entrada a 3,7 km NW de Congonhas do Norte, estrada pelo alto da serra em local denominado localmente Retiro dos Pereiras, $18^{\circ} 50^{\prime} 60^{\prime \prime} \mathrm{S}, 43^{\circ} 44^{\prime} 60^{\prime \prime} \mathrm{W}, 1,280 \mathrm{~m}, 4$ Feb 2009 (fl), J. R. Pirani et al. 5752 (SPF); Santana do Riacho, Serra do Cipó, km 125 da rodovia Belo Horizonte - Conceição do Mato Dentro, em frente a estátua do Velho Juca, 1,320-1,370 m, 7 Dec 1991 (fl), J. R. Pirani et al. in CFSC 12809 (SPF); Jaboticatubas, km 142 da rodovia Lagoa Santa Conceição do Mato Dentro, 9 Dec 1971 (fl), M. Sazima 13353 (UEC); Jaboticatubas, Serra do Cipó, km 132 rodovia Lagoa Santa/Conceição do Mato Dentro, 10-15 Dec 1973 (fl), J. Semir \& M. Sazima 4772 (SP); Santana do Riacho, Parque Nacional da Serra do Cipó, Casa da Guarda, $19^{\circ} 17^{\prime}$ 11.1"S, 4334'23.4"W, 1,232 m, 7 Dec 2010 (fl), A. A. Vale et al. 24 (BHCB); Santana do Riacho, Parque Nacional da Serra do Cipó, Casa da Guarda, $19^{\circ} 15^{\prime} 0.6^{\prime \prime} \mathrm{S}, 43^{\circ} 32^{\prime} 36.4^{\prime \prime} \mathrm{W}, 1,408 \mathrm{~m}, 7 \mathrm{Dec} 2010$ (fl), A. A. Vale et al. 25 (BHCB); Buenópolis, Parque Nacional das Sempre-Vivas, Campo a sudoeste/oeste da casa do pesquisador, $17^{\circ} 55^{\prime} 4.2^{\prime \prime} \mathrm{S}, 43^{\circ} 47^{\prime} 20.4^{\prime \prime} \mathrm{W}, 1,290$ m, 20 Feb 2012 (fl, fr), A. A. Vale E V.A.O. Dittrich 83 (BHCB); Conceição do Mato Dentro, Tabuleiro, alto da cachoeira, 1,149 m, 194 $4^{\prime} 59^{\prime \prime} \mathrm{S}, 43^{\circ} 33^{\prime}$ 57"W, 19 Feb 2004 (fl), C. van den Berg 1343 (HUEFS, mixed with $H$. hippocrepica); Serra do Cipó, Nov 1997 (fl), F. Vitta \& Belinello s. n. (UEC 140080 \& 140192).
Habenaria hippocrepica J. A. N. Bat. \& Bianch., sp. nov.TYPE: BRAZIL. Minas Gerais: Serra do Cipó, cerca de $8 \mathrm{~km}$ após o entroncamento para Morro do Pilar na direção de Conceição do Mato Dentro, próximo do km 136, 12 Mar 1999 (fl), J. A. N. Batista \& L. B. Bianchetti 899 (holotype: BHCB; isotypes: CEN, HUEFS, MBM, RB, SP).

Similar to $H$. espinhacensis, but distinct by the inflorescence usually congested, with (1.0)1.5-3.5(5.0) flowers per $\mathrm{cm}$ of inflorescence, shorter pedicellate ovary (6.0-10.5 mm long), shorter spur (4.1-6.8 mm long), petal anterior segment (0.9-) 1.1-1.3(-1.5) times longer than the posterior segment, long connective, anther canals and rostellum arms slightly convergent towards their apices, and rostellum mid-lobe apex rounded. Also similar to $H$. quadriferricola, but distinct by its longer anterior petal segment $(3.6-7.0 \mathrm{~mm})$, longer lip lateral segments $(4.0-7.6(-10.4) \mathrm{mm})$, and sepals not (or inconspicuously) aristate (arista 0.0-0.4 mm long).

Terrestrial caulescent herb. Tuberoid ellipsoid, $11 \times 4 \mathrm{~mm}$. Roots few, about $0.7 \mathrm{~mm}$ wide. Stem erect to slightly sinuose, 9-26(-44) cm, including the inflorescence, 0.5-1.8 mm wide. Leaves (3-)4-7(-9), base sheathing, sheath closed, blade ascending, linear, largest at the lower half or center of the stem, 3.6-12.0 × 0.2-0.5 cm, membranaceous, acuminate. Inflorescence $2-12(-22) \mathrm{cm}$, usually many flowered and congest, spiral, (1.0-)1.5-3.5(-5.0) flowers for $\mathrm{cm}$ of inflorescence; bracts ovate, about the same size as the pedicellate ovary, $6.0-10.5 \times 1.5$ $3.0 \mathrm{~mm}$, caudate. Flowers 4-35(-48), resupinate, glabrous, greenish; pedicellate ovary ascending to inclined, $6.0-10.5 \mathrm{~mm}$ long; ovary arched to strongly arched, 4.8-7.5 mm long; pedicel short, 1.1-3.0 mm long. Sepals green, margins smooth, acute, arista absent or inconspicuous, $0.0-0.4 \mathrm{~mm}$; dorsal sepal concave, ovate when flattened, 3.1-4.8 × 2.8-4.4 mm; lateral sepals obliquely lanceolate, 3.2-5.1 × 1.7-2.4 mm, acute. Petals bipartite, base whitish, becoming light green to greenish yellow towards the segment apices; posterior segment linearlanceolate, 3.4-6.2 $\times 0.8-1.2 \mathrm{~mm}$, adherent to the dorsal sepal or projected outwards from the median part towards the apex, acute; anterior segment erect, reflexed, filiform, inserted at the base of the posterior segment, 3.6-7.0 mm, (0.9-)1.11.3(-1.5) times as long as the posterior segment. Lip tripartite; undivided basal part short, 0.8-1.0 × 0.9-1.1 mm, whitish; lateral segments perpendicular to the median segment, linear-filiform, 4.0-7.6(-10.4) mm, (1.0-)1.2-1.5(-1.7) times as long as the posterior segment; median segment linear, curved backwards, 3.0-5.2(-6.8) × 0.4-0.5 mm; spur parallel to pedicellate ovary, free from the bracts, linear, shorter than the pedicellate ovary, 4.1-6.8 mm long, greenish, green. Gynostemium erect, $1.4-1.7 \mathrm{~mm}$ high; connective emarginate, long, 1.4-2.3 $\mathrm{mm}$ between the anther loculi, light green; lateral appendages (auricles) small to median sized, $0.5-1.1 \times 0.3-0.5 \mathrm{~mm}$, whitish. Anther bilocular, loculi parallel, 1.0-1.2 mm high, canals short, $0.4-0.5 \mathrm{~mm}$ long; hemipollinaria separate; caudicle $0.7 \mathrm{~mm}$ long, viscidia deltoid, $0.15 \times 0.15 \mathrm{~mm}$, spaced $0.5-0.9 \mathrm{~mm}$ from each other. Stigmatophores (stigma lobes) 2, closely parallel, 1.2-2.0 mm long, whitish, receptive surface slightly convex, margins thickened, turned frontwards, $0.6-1.0 \mathrm{~mm}$ long. Rostellum 1.2-2.1 mm long, whitish; mid-lobe flattened to triangular, fleshy, completely placed between the anther loculi, 0.4-0.9 mm high, apex rounded, when developed slightly curved frontwards; side-lobes sulcate, slightly convergent towards apices, 0.5$1.4 \mathrm{~mm}$ long. 
Distribution-Most of the collections of this species are from the central region of the Espinhaço Range in Minas Gerais, from Serra do Cipó to the Diamantina plateau, but a few records also extend north to Botumirim.

Habitat, Ecology, and Phenology-Habenaria hippocrepica occurs from 1,000-1,500 m a. s. 1., growing in seasonally wet grasslands (campo limpo estacionalmente úmido) over dark, sandy-clay soils, and frequently associated with rock outcrops in campo rupestre vegetation. Flowering occurs from January to April, but is concentrated in February and March, from the peak to the end of the rainy season (Table 1). In the same way as for $H$. reflexicalcar, most collections of this species made by the authors were in areas that had recently burned and, as with most other Habenaria and terrestrial orchids from open grasslands (Jones 1993), the flowering of this species is greatly enhanced by brushfires during the dry season. Other Habenaria species, such as H. ayangannensis, H. magniscutata Catling, H. mystacina Lindl., and H. pubidactyla subsp. pubidactyla, occur in the same areas and flower at about the same time.

Etymology - From the Latin hippocrepicus (shaped like a horseshoe), referring to the connective of the species, which is horseshoe shaped and proportionally longer (in relation to the size of the flower) than most other Neotropical species of the genus.

Conservation Status-Based on the World Conservation Union Red List Categories and Criteria (IUCN 2001), this new taxon can be tentatively classified as of least concern (LC). The species is common throughout its distribution range and forms large populations, several of which occur inside federal or state conservation areas.

Notes-H. hippocrepica was apparently first collected by A. de Saint-Hilaire between 1816 and 1821 in an unspecified location in Minas Gerais State, being identified as $H$. parviflora Lindl. by Cogniaux. Another collection (Glaziou 19896) was also identified by Cogniaux as $H$. retusa Barb. Rodr., now a synonym of $H$. balansae Cogn. More recently, Pabst identified some specimens as $H$. belloi Schltr. or $H$. subfiliformis, while most collections of the species remained indeterminate in various herbaria.

Habenaria hippocrepica is similar to $H$. quadriferricola and $H$. espinhacensis. It differs from the former by the shorter sepal arista (0-0.4 $\mathrm{mm}$ vs. $0.2-0.8 \mathrm{~mm}$ in $H$. quadriferricola), longer anterior petal segment (3.6-7.0 $\mathrm{mm}$ vs. $1.1-1.9 \mathrm{~mm})$, and longer lateral lip segments (4.0-7.6(-10.4) mm vs. 1.8-3.8 mm). It differs from $H$. espinhacensis by the congested inflorescence ((1-)1.5-3.5(-5) vs. (0.7-)0.9-1.4(-1.8)) flowers per cm of inflorescence), shorter pedicellate ovary (6.0-10.5 mm vs. 12-14 mm), shorter spur (4.1-6.8 mm vs. 9-12 mm), petal anterior segment (0.9-)1.1-1.3(-1.5) times longer than the posterior segment (vs. (1.2-)1.5-2 times longer than the posterior segment), longer connective (1.4-2.3 mm vs. $0.5-0.9 \mathrm{~mm})$, rostellum arms convergent (vs. parallel), and rostellum mid-lobe with rounded apex (vs. acute to subacute) (Table 2).

Habenaria hippocrepica was identified by Pabst in some herbaria as H. belloi and H. subfiliformis (Menezes 797 and 798 (HB), Ghillány s.n. (HB 57919)). Habenaria subfiliformis is distinct from $H$. hippocrepica by its flowers being more distantly spaced on the inflorescence (0.9-1.5 flowers per cm inflorescence vs. (1-)1.5-3.5(-5) flowers per $\mathrm{cm}$ of inflorescence in $H$. hippocrepica), smaller flowers, shorter anterior petal segments (2.3-4.0 $\mathrm{mm}$ vs. $3.6-7.0 \mathrm{~mm}$ in H. hippocrepica), and shorter lateral lip segments (3.4-4.4 mm vs. 4.0-7.6 (-10.4) mm in $H$. hippocrepica). Habenaria belloi is an obscure species, known only from the type material that was lost during World War II in the Berlin herbarium. No duplicates or illustrations are known. The description of $H$. belloi generally fits $H$. hippocrepica (as well as other similar species), and we have been unable to reach a conclusion about its identity based on just the original description. A key difference seems to be their geographic distributions. The type of $H$. belloi was from Rio de Janeiro State, while H. hippocrepica is restricted to the Espinhaço Range in Minas Gerais.

In terms of the overall morphologies of the plants and flowers, $H$. hippocrepica is similar to other species with slender plants, linear leaves, small flowers, and long lateral segments of the petals and lip, such as $H$. ayangannensis, $H$. canastrensis, $H$. ludibundiciliata, $H$. psammophila, and $H$. pseudoculicina. Its main distinctive character is the length of the connective (1.4-2.3 mm long) (Figs. 3H, 4G), which is proportionally longer in relation to the size of the gynostemium than in other Neotropical species. Other distinctive characters are its spiral and (usually) many-flowered, congested inflorescence ((1-)1.5-3.5(-5) flowers per $\mathrm{cm}$ of inflorescence). In most of the species mentioned above the flowers are usually few, spaced along the inflorescence $((0.8) 0.9-1.2(1.3)$ flowers

TABLE 2. Comparison of the diagnostic characters for the species of Habenaria from the Espinhacenses clade.

\begin{tabular}{|c|c|c|c|c|}
\hline & H. reflexicalcar & H. hippocrepica & H. quadriferricola & H. espinhacensis \\
\hline Plant size, including inflorescence $(\mathrm{cm})$ & $11-33(-48)$ & $9-26(-44)$ & $10-24(-43)$ & $(12-) 19-53(-68)$ \\
\hline Number of flowers $\mathrm{cm}^{-1}$ inflorescence & $1.3-2.0(-2.4)$ & $(1.0-) 1.5-3.5(-5.0)$ & $(1.2-) 1.5-2.7(-3.4)$ & $(0.7-) 0.9-1.4(-1.8)$ \\
\hline Length of ovary and pedicel (mm) & $6.0-10.0$ & $6.0-10.5$ & $(5.4-) 8.0-10.6$ & $(8-) 11-14$ \\
\hline Lateral sepals arista length (mm) & $0.0-0.3$ & $0.0-0.4$ & $0.4-0.9$ & $0.0-0.6$ \\
\hline Posterior petal length (mm) & $2.7-5.1$ & $3.4-6.2$ & $4.0-4.7$ & $4.8-6.7$ \\
\hline Anterior petal length (mm) & $4.1-9.0$ & $3.6-7.0$ & $1.0-2.0$ & $7.0-12.0$ \\
\hline $\begin{array}{l}\text { Anterior petal/posterior petal } \\
\text { length ratio }\end{array}$ & $(1.1-) 1.4-1.9(-2.1)$ & $(0.9-) 1.1-1.3(-1.5)$ & $0.2-0.4$ & $(1.2-) 1.5-2.0$ \\
\hline Lip median segment length (mm) & $3.2-5.4$ & $3.0-5.2(-6.8)$ & $(3.3-) 4.0-4.3(-5.6)$ & $5.5-9.0$ \\
\hline Lip lateral segments length (mm) & $4.8-8.5$ & $4.0-7.6(-10.4)$ & $1.8-4.0$ & $6.0-11.0$ \\
\hline $\begin{array}{l}\text { Lip lateral segments/median } \\
\text { segment length ratio }\end{array}$ & $0.8-1.8(-2.0)$ & $(1.0-) 1.2-1.5(-1.7)$ & $0.4-0.6(-0.9)$ & $(1.1-) 1.3-1.6$ \\
\hline Spur orientation & reflexed, erect & deflexed & deflexed & deflexed \\
\hline Spur length (mm) & $4.7-9.1$ & $4.1-6.8$ & $4.0-5.9(-6.3)$ & $7.0-12.0$ \\
\hline $\begin{array}{l}\text { Connective length between anther } \\
\text { loculi (mm) }\end{array}$ & short, $0.6-0.8$ & long, $1.4-2.3$ & long, $0.8-1.8$ & short $0.5-0.9$ \\
\hline Rostellum mid-lobe apex & obtuse & rounded & rounded to acute & acute to subacute \\
\hline Rostellum side-lobes orientation & parallel to slightly convergent & slightly convergent & slightly convergent & parallel \\
\hline
\end{tabular}




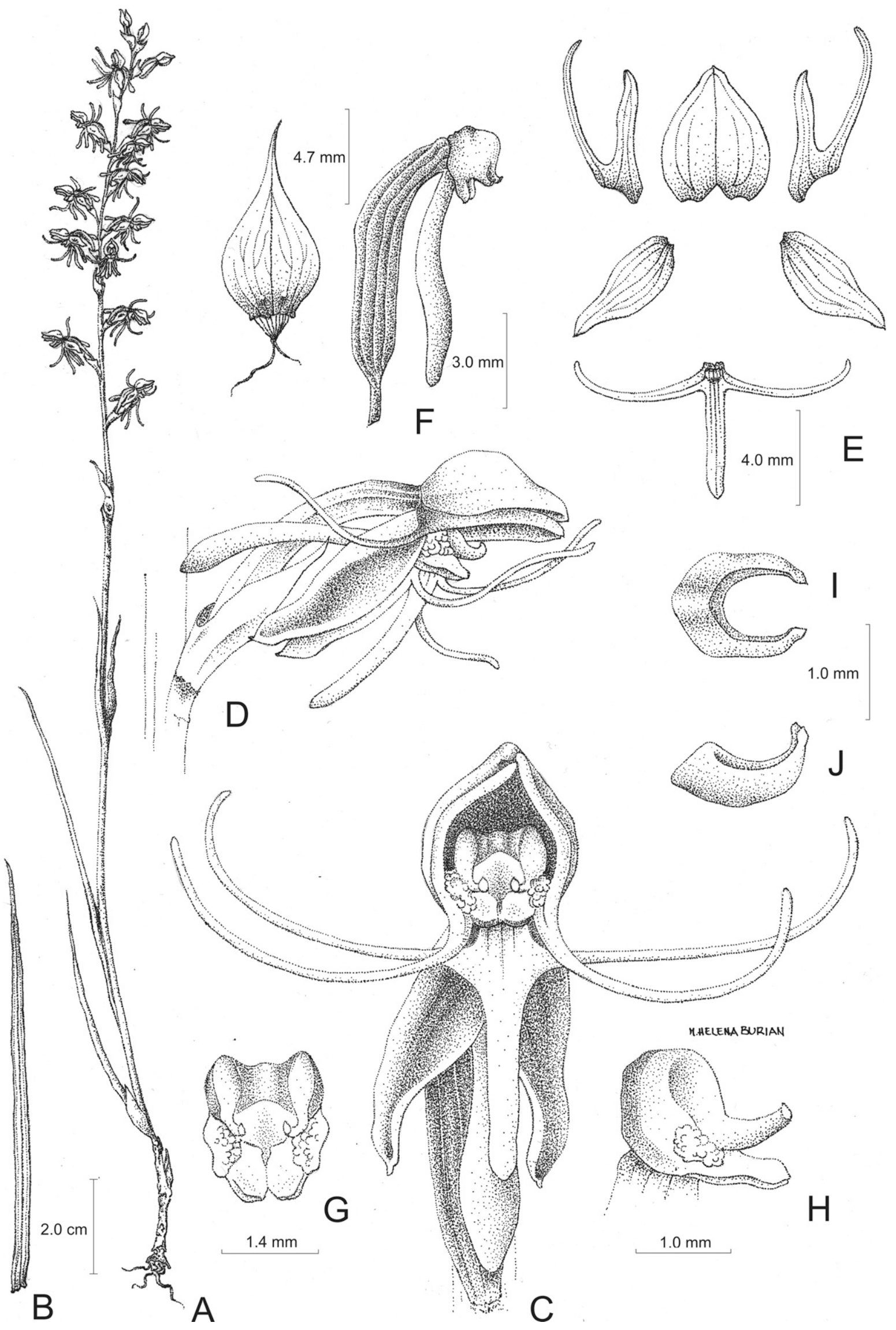

Fig. 4. Habenaria hippocrepica. A. Habit. B. Leaf. C. Flower, front view. D. Flower, lateral view. E. Dissected perianth. F. Bract, pedicellate ovary, spur and gynostemium, lateral view. G. Gynostemium, front view. H. Gynostemium, lateral view. I. Rostellum, upper view. J. Rostellum, lateral view. All based on Batista \& Bianchetti 899. Drawn by Maria Helena Burian. 
per $\mathrm{cm}$ of inflorescence in $H$. ludibundiciata, for example) and arranged only on one side of the inflorescence.

Long connectives are found in some African species and sections of the genus, such as Habenaria sect. Multipartitae Kraenzl. (H. praestans Rendle, connective $=11-16 \mathrm{~mm}$ long), Habenaria sect. Kryptostoma Summerh. (H. tentaculigera Rchb.f. $=14-16 \mathrm{~mm}$ long), and H. excelsa Thomas \& Cribb (= 8-9 mm long). Such long connectives do not occur in any Neotropical species of the genus.

Similar to other species of the genus, $H$. hippocrepica is variable in some of its characters, such as plant size (which ranges from $9-46 \mathrm{~cm}$ ). Some populations, however, like the one from Presidente Kubitscheck County, had consistently smaller plants and flowers and very congested inflorescences (Fig. 3E). These populations also showed some differences in terms of their gynostemium morphologies, including small auricles $(0.5 \times 0.3 \mathrm{~mm}$ vs. $1.1 \times 0.5 \mathrm{~mm}$ in other populations), and a longer mid-lobe of the rostellum (0.8-0.9 mm vs. $0.4-0.5 \mathrm{~mm}$ in other populations), resembling the rostellum of $H$. quadriferricola. As these variant populations are morphologically similar to $H$. hippocrepica overall, we kept them within the concept of this species, although further studies using biosystematics approaches (including morphometrics and population genetics) may show that they deserve recognition as a distinct taxon.

The ovary in most populations of the species is arched to strongly arched, and the front side of the flowers is turned downwards (Figs. 3D, 4D), implying that pollinators must approach them from below. The spur is shorter than the pedicellate ovary, and parallel to it in most cases. Occasionally, the spur is slightly reflexed, but never erect as in $H$. reflexicalcar. One specimen in the sample Zappi et al. 10555 (CEN, SPF) had exceptionally long pedicels $(6.0-10.0 \mathrm{~mm}$ long vs. 1.1-3.0 mm long in all other specimens examined). This variant was considered an abnormality and was not included in the description of the species.

Additional Specimens Examined-BRAZIL. Minas Gerais: Serra do Cipó, entre Santana do Riacho e Conceição do Mato Dentro, MG-010, cerca de 7-8 km após o entroncamento para Morro do Pilar, cerca de $40 \mathrm{~km}$ NE de Cardeal Mota em direção a Conceição do Mato Dentro, 31 Mar 2003 (fl), J. A. N. Batista 1410 (CEN); Presidente Kubitschek, BR-259, cerca de $2 \mathrm{~km}$ após a entrada para Presidente Kubitschek, ca. de $35 \mathrm{~km}$ O de Serro em direção a Datas, 2 Apr 2003 (fl), J. A. N. Batista 1425 (CEN, BHCB); Presidente Kubitschek, cerca de $2.8 \mathrm{~km}$ do entrocamento para Presidente Kubitschek, na altura do km 442 da BR-259 no sentido para datas, $18^{\circ} 34^{\prime} \mathrm{S}, 4^{\circ} 35^{\prime} \mathrm{W}, 1,170 \mathrm{~m}, 14 \mathrm{Feb} 2007$ (fl), J. A. N. Batista et al. 1920 (BHCB); Diamantina, $13 \mathrm{~km} \mathrm{~S}$ de Diamantina na estrada para Milho Verde, $18^{\circ} 20^{\prime} \mathrm{S}, 43^{\circ} 32^{\prime} \mathrm{W}, 1,274 \mathrm{~m}, 15 \mathrm{Feb} 2007$ (fl), J. A. N. Batista et al. 1948 (BHCB); Serro, Milho Verde, Lageado, 18 $27^{\circ} \mathrm{S}$, $43^{\circ} 28^{\prime} \mathrm{W}, 1,076 \mathrm{~m}, 16 \mathrm{Feb} 2007$ (fl), J. A. N. Batista et al. 1952 (BHCB); Conceição do Mato Dentro, Parque Municipal Ribeirão do Campo, campos na parte de cima da Cachoeira do Tabuleiro, $19^{\circ} 05^{\prime} \mathrm{S}, 43^{\circ} 33^{\prime} \mathrm{W}, 1,071 \mathrm{~m}$, 17 Feb 2007 (fl), J. A. N. Batista et al. 1963 (BHCB); São Gonçalo do Rio Preto, Parque Estadual do Rio Preto, trilha para a Chapada, antes da Lapa da Santa, $18^{\circ} 10^{\prime} \mathrm{S}, 43^{\circ} 19^{\prime} \mathrm{W}, 1,131 \mathrm{~m}, 20 \mathrm{Mar} 2007$ (fl), J. A. N. Batista et al. 2025 (BHCB); São Gonçalo do Rio Preto, Parque Estadual do Rio Preto, Chapada, base do Pico dois Irmãos, 20 Mar 2007 (fl, fr), J. A. N. Batista et al. 2030 (BHCB, mixed with $H$. ayangannensis); São Gonçalo do Rio Preto, Parque Estadual do Rio Preto, trilha entre o alojamento na Chapada e o Córrego das Éguas, 21 Mar 2007 (fl), J. A. N. Batista et al. 2033 (BHCB); Diamantina, Parque Nacional das Sempre Vivas, Campos de São Domingos,

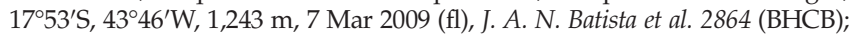
Diamantina, campos a direita da MG-220, sentido Diamantina para Conselheiro Mata, cerca de 20-21 km do entroncamento com a BR-368, $18^{\circ} 17^{\prime} 44.4^{\prime \prime} \mathrm{S}, 43^{\circ} 50^{\prime} 37.5^{\prime \prime} \mathrm{W}, 1,233 \mathrm{~m}, 6$ Jan 2011 (fl), J. A. N. Batista et al. 3140a (BHCB); Datas, arredores da cidade, 23 Feb 1983 (fl, fr), I. Cordeiro \& E. Simonis in CFCR 4063 (SPF); Congonhas do Norte, Serra da Carapina (Serra Talhada segundo folha do IBGE), $18^{\circ} 52^{\prime} \mathrm{S}, 43^{\circ} 14^{\prime} \mathrm{W}$, 1,310 m, 2 Mar 1998, R. C. Forzza et al. 704 (SPF); Serra do Espinhaço,
40 km NW Diamantina, 1200 m, 15 Feb 1972, A. de Ghillány s. n. (HB 57919); A. Glaziou 19896 (K, P); Conceição do Mato Dentro, MG 010, próximo ao morro com uma cruz, $19^{\circ} 09^{\prime} 45^{\prime \prime} \mathrm{S}, 43^{\circ} 30^{\prime} 59^{\prime \prime} \mathrm{W}, 1,352 \mathrm{~m}$, 31 Mar 2011 (fl), B. L. Lau \& A. Massensini Jr. 55 (BHCB); Datas, km 607 da rodovia Diamantina/Datas (BR 367), $8.7 \mathrm{~km}$ ao norte de Datas a partir do trevo da rodovia Datas-Serro (BR 267) e $18.3 \mathrm{~km}$ ao sul de Diamantina, a partir do trevo na saída da cidade, 1 Feb 2000 (fl), R. MelloSilva \& R. C. Forzza 1785 (SPF); Diamantina, ca. 8 km do asfalto (Guinda), 22 Mar 1978, N. L. Menezes 797 (HB); Diamantina, estrada Guinda Diamantina, $10 \mathrm{~km}$ de Diamantina, 22 Mar 1978 (fl), N. L. Menezes 798 (HB); Trinta Réis, estrada Serro - Diamantina, 27 Jan 1986 (fl), N. L. Menezes et al. in CFCR 9230 (BHCB, SP, SPF); São Gonçalo do Rio Preto, Fazenda Raízes, $18^{\circ} 05^{\prime} \mathrm{S}, 43^{\circ} 23^{\prime} \mathrm{W}, 850$ m, Feb 2009 (fl), N. F. O. Mota et al. 1503 (BHCB); Conceição do Mato Dentro, Parque Natural Municipal do Ribeirão do Campo, $10 \mathrm{Feb} 2003$ (fl), R. C. Mota \& P. L. Viana 1702 (BHCB); Serro, Milho Verde, Lageado, 1 Feb 2003 (fl), R. C. Mota 1731 (BHCB, CEN); Conceição do Mato Dentro, Parque Natural Municipal do Ribeirão do Campo, 25 Mar 2005 (fl), R. C. Mota 2919 (BHCB); Serra do Cipó, Currais, $19^{\circ} 40^{\prime} \mathrm{S}, 43^{\circ} 53^{\prime} \mathrm{W}, 1,454 \mathrm{~m}$, 21 Mar 2008 (fl), A. C. D. Munhoz et al. 169 (BHCB); 1949'S, 4350'W, 1,525 m, 21 Mar 2008 (fl), A. C. D. Munhoz et al. 175 (BHCB); Serra do Cipó, Currais, Campo do Boi, 1949'S, 4350' W, 1,525 m, 22 Mar 2008 (fl), A. C. D. Munhoz et al. 183 (BHCB); Presidente Kubischeck, rodovia sentido Presidente Kubischeck/Serro, cerca de $7 \mathrm{~km}$ da cidade, $12 \mathrm{Feb}$ 2001 (fl), E. R. Pansarin \& A. O. Simões 813 (CEN, UEC); Milho Verde, estrada de terra sentido Serro/Milho Verde, cerca de $10 \mathrm{~km}$ de Serro, 14 Feb 2001 (fl), E. R. Pansarin \& A. O. Simões 831 (CEN, UEC); Congonhas do Norte, Serra Talhada, setor nordeste da Serra do Cipó, $6.8 \mathrm{~km} \mathrm{SW}$ da estrada Congonhas do Norte - Gouveia, entrada a $3.7 \mathrm{~km}$ NW de Congonhas do Norte, estrada pelo alto da serra em local denominado localmente Retiro dos Pereiras, Cachoeira Choro das Virgens (braço do Córrego Barbado, nascentes do Rio Preto), 18 $8^{\circ} 50^{\prime} 33.3^{\prime \prime} \mathrm{S}, 43^{\circ} 45^{\prime}$ 32.1"W, 1,200 m, 19 Jan 2007, J. R. Pirani et al. 5583 (SPF); Congonhas do Norte, Serra Talhada, setor nordeste da Serra do Cipó, $9 \mathrm{~km} \mathrm{~S}$ de Congonhas do Norte na estrada para Conceição do Mato Dentro, entrada para Extrema seguindo $11 \mathrm{~km}$, Fazenda Imbaúbas, 18 ${ }^{\circ} 55^{\prime} 48^{\prime \prime} \mathrm{S}, 43^{\circ} 40^{\prime} 17^{\prime \prime}$ W, 1,130 m, 20 Jan 2007, J. R. Pirani et al. 5601 (SPF); Congonhas do Norte, Serra Talhada, setor nordeste da Serra do Cipó, $9 \mathrm{~km} \mathrm{~S}$ de Congonhas do Norte na estrada para Conceição do Mato Dentro, entrada para Extrema seguindo ca. $11 \mathrm{~km}$, estrada para Lapinha, $18^{\circ} 56^{\prime} 38.4^{\prime \prime} \mathrm{S}, 43^{\circ} 40^{\prime} 54^{\prime \prime} \mathrm{W}, 1,419 \mathrm{~m}$, 3 Feb 2009, J. R. Pirani et al. 5725 (SPF); Santana do Riacho, Serra do Cipó, $18^{\circ} 55^{\prime} \mathrm{S}, 43^{\circ} 54^{\prime} \mathrm{W}$, Santana do Pirapama, Fazenda Inhame (Serra Mineira), 22 Mar 1982 (fl), J. R. Pirani et al. in CFSC 8120 (SP); São Gonçalo do Rio Preto, Parque Estadual do Rio Preto, Itaobal, próximo a Lapa da Santa, $18^{\circ} 09^{\prime} \mathrm{S}, 43^{\circ} 19^{\prime} \mathrm{W}, 1,032 \mathrm{~m}, 28 \mathrm{Feb} 2008$ (fl), A. J. Ramalho et al. 1 (BHCB); Diamantina, estrada para Conselheiro Mata, $8-9 \mathrm{~km}$ após a entrada desta estrada na BR $259,18^{\circ} 17^{\prime} 32^{\prime \prime} \mathrm{S}, 43^{\circ} 44^{\prime} 18^{\prime \prime} \mathrm{W}$, campo rupestre, solo arenoso úmido, $13 \mathrm{Feb}$ 2007, P. L. Ribeiro et al. 224 (HUEFS 119725 \& 119726, mixed with H. humilis Cogn.); 1816-1821, A. de Saint-Hilaire B1 930 (P); Jaboticatubas, km 121 da rodovia Lagoa Santa - Conceição do Mato Dentro, 9 Feb 1972, M. Sazima 13404 (UEC); Santana do Pirapama, Serra do Cipó (Serra da Lapa), Distrito de São José da Cachoeira, trilha da Senhorinha, $18.9422^{\circ} \mathrm{S}$, $43.7498^{\circ} \mathrm{W}, 1,300 \mathrm{~m}$, campo rupestre, $19 \mathrm{Feb}$ 2007, V. C. Souza et al. 32824 (ESA); V. C. Souza et al. 32832 (ESA); V. C. Souza et al. 32833 (ESA); Santana do Riacho, Serra do Cipó, Vellozia gigantea, $19^{\circ} 14^{\prime} 50.3^{\prime \prime} \mathrm{S}, 43^{\circ} 30^{\prime} 41.5^{\prime \prime} \mathrm{W}$, 1,277 m, 18 Feb 2012 (fl), A. A. Vale \& V. A. O. Dittrich 63 (BHCB); Serro, Capivari, no Lajeado na beira da estrada entre Milho Verde e Capivari, entrando pela estrada que vai para Capivari, $18^{\circ} 28^{\prime} 40.7^{\prime \prime} \mathrm{S}, 43^{\circ} 27^{\prime} 41.6^{\prime \prime} \mathrm{W}$, 1,094 m, 19 Feb 2012, A. A. Vale \& V. A. O. Dittrich 67 (BHCB); Bocaiúva, Parque Nacional das Sempre-Vivas, estrada para Campo Triste, próximo ao Renegado, aprox. $8 \mathrm{~km}$ da casa do pesquisador, $17^{\circ} 53^{\prime} 45^{\prime \prime} \mathrm{S}, 43^{\circ} 45^{\prime} 24^{\prime \prime} \mathrm{W}$, 1,310 m, 21 Feb 2012, A. A. Vale \& V. A. O. Dittrich 91 (BHCB); Bocaiúva, Parque Nacional das Sempre-Vivas, estrada para Campo Triste, próximo ao Renegado, aprox. $16 \mathrm{~km}$ da casa do pesquisador, no Renegado, após o campo grande, $17^{\circ} 48^{\prime} 11^{\prime \prime} \mathrm{S}, 43^{\circ} 46^{\prime} 51^{\prime \prime} \mathrm{W}, 1,230 \mathrm{~m}, 21 \mathrm{Feb} 2012$, A. A. Vale \& V. A. O. Dittrich 101 (BHCB); Serro, Capivari, estrada para o Pico do Itambé, aprox. $3.5 \mathrm{~km}$ de Capivari, 23 Feb 2012, A.A. Vale \& V. A. O. Dittrich 111 (BHCB); Serro, Capivari, estrada entre Capivari e Milho Verde, a $5.5 \mathrm{~km}$ do trevo de Milho Verde/Capivari/Serro, $23 \mathrm{Feb}$ 2012, A. A. Vale \& V. A.O. Dittrich 113 (BHCB); Presidente Kubitschek, 18 $34^{\prime} 17^{\prime \prime} \mathrm{S}$, $43^{\circ} 35^{\prime} 42^{\prime \prime} \mathrm{W}, 1145 \mathrm{~m}, 11 \mathrm{Feb} 2013$, A. A. Vale et al. 234 (BHCB); Santana do Riacho, Parque Nacional da Serra do Cipó, trilha para as Vellozia gigantea, 21 Apr 2013 (fl, fr), A. A. Vale et al. 273 (BHCB); Santana do Riacho, Parque Nacional da Serra do Cipó, Morro da Cruz, 21 Apr 2013 (fl, fr), A. A. Vale et al. 279 (BHCB); Botumirim, Campina do Bananal, 1,300 m, 1 Mar 2000 (fl), M. F. Vasconcelos \& S. D' Angelo Neto s. n. (BHCB 50872 \& 50875); Conceição do Mato Dentro, estrada na APA do Intendente, $19^{\circ} 8^{\prime} 37^{\prime \prime}$, 


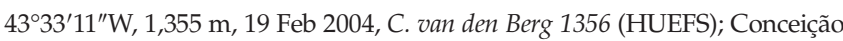
do Mato Dentro, Tabuleiro, alto da cachoeira, $19^{\circ} 4^{\prime} 59^{\prime \prime} \mathrm{S}, 43^{\circ} 33^{\prime} 57^{\prime \prime} \mathrm{W}, 1,149 \mathrm{~m}$, $19 \mathrm{Feb} 2004$, C. van den Berg 1343 (HUEFS, mixed with H. reflexicalcar); São Gonçalo do Rio Preto, Parque Estadual do Rio Preto, subida para o Pico dois Irmãos, 10 Apr 2005 (fl), P. L. Viana \& L. E. Lopes 2812 (BHCB, RB); Serra do Cipó, Nov 1997, F. Vitta \& Belinello s. n. (UEC 140192, mixed with $H$. reflexicalcar); Santana do Pirapama, Serra do Cipó, estrada São José da Cachoeira-Inhame, trilha da Senhorinha, $19^{\circ} 0^{\prime} 0^{\prime \prime} \mathrm{S}, 43^{\circ} 45^{\prime} 47^{\prime \prime} \mathrm{W}, 1,500 \mathrm{~m}$, 19 Feb 2007, D. C. Zappi et al. 828 (ESA, SPF, mixed with Habenaria sp.); Diamantina, estrada de terra para São João da Chapada, $14 \mathrm{~km}$ de Diamantina, 16 Apr 1987 (fl), D. C. Zappi et al. in CFCR 10555 (CEN, SPF).

Habenaria quadriferricola J. A. N. Bat. \& B. M. Carvalho, sp. nov.-TYPE: BRAZIL. Minas Gerais: Catas Altas, Serra do Caraça, 16 Feb 2002 (fl), R. C. Mota 1724 (holotype: $\mathrm{BHCB}$; isotype: $\mathrm{CEN})$.

Similar to $H$. hippocrepica, but distinct by usually having sepals with conspicuous aristae up to $0.8 \mathrm{~mm}$ long, anterior petal segment 1.0-2.0 $\mathrm{mm}$ long, shorter than posterior segment, lateral lip segments $1.8-4.0 \mathrm{~mm}$ long, shorter than median segment, and growing at 1,600-1,900 $\mathrm{m}$ a. s. 1 . in high altitude fields of Quadrilátero Ferrífero in the southern region of the Espinhaço Range.

Terrestrial slender, caulescent herb. Tuberoid and roots not examined. Stem erect to slightly sinuose, $10-24(-43) \mathrm{cm}$, including the inflorescence, $0.6-1.9 \mathrm{~mm}$ wide. Leaves 3-6, largest 1-3, at the center of the stem, base sheathing, sheath closed, blade partially adpressed to the stem or ascending, linear to filiform, 5-14 × 0.2-0.6 cm. Inflorescence (1.5-)3.0$10.0(-15.0) \mathrm{cm}$ long, spiral, few to many flowered, (1.2-)1.52.7(-3.4) flowers per $\mathrm{cm}$ of inflorescence; bracts lanceolate, $7.0-13.0(-19.0) \times 2.3-4.0 \mathrm{~mm}$, usually shorter than the pedicellate ovary, acuminate. Flowers $(2-) 5-25(-36)$, resupinate, glabrous, greenish; pedicellate ovary ascending to inclined, (5.4-)8.0-10.6 mm long; ovary slightly to strongly arched, (4.2-)6.0-8.2 mm long, pedicel 1.2-2.7 mm long. Sepals green, margins smooth, apex acute, arista usually conspicuous, 0.4-0.9 mm long; dorsal sepal concave, ovate when flattened, (2.8-)3.7-4.2(-5.0) × (2.5-)3.0-3.4(-4.3) mm; lateral sepals obliquely lanceolate, $3.3-4.7(-6) \times 1.5-1.8(-2.8) \mathrm{mm}$, acute. Petals bipartite, light green, base whitish; towards the segments apex light green; posterior segment falcate, 4.0$4.7 \times 0.8-0.9 \mathrm{~mm}$, free from the dorsal sepal, acute; anterior segment reflexed, inserted at the base of the posterior segment, linear, $1.0-2.0 \mathrm{~mm}, 0.2-0.4$ times as long as the posterior segment. Lip tripartite, light green, base whitish; undivided basal part short; 0.6-0.7 $\times 0.7-0.9 \mathrm{~mm}$; lateral segments perpendicular to the medium segment, linear-filiform, $1.8-4.0 \mathrm{~mm}$, 0.4-0.6(-0.9) times as long as the median segment; median segment linear, curved backwards, (3.3-)4.0-4.3(-5.6) $\times 0.4$ $0.5(-0.8) \mathrm{mm}$; spur deflexed, free from the bracts, linear, shorter than the pedicellate ovary, 4.0-5.9(-6.3) $\mathrm{mm}$ long, green. Gynostemium erect, 1.6-1.9 $\mathrm{mm}$ high; connective retuse, long, 0.8-1.8 $\mathrm{mm}$ between the anther loculi, middle thickened, light green; lateral appendages (auricles) small, 0.4$0.6 \times 0.3-0.4 \mathrm{~mm}$, whitish. Anther bilocular, loculi parallel, 0.9-1.3 mm high, canals short, $0.3-0.4 \mathrm{~mm}$ long; hemipollinaria separate, viscidia $0.2 \times 0.2 \mathrm{~mm}$, spaced $0.5-0.8 \mathrm{~mm}$ from each other. Stigmatophores (stigma lobes) 2 , closely parallel, 1.3-1.4 mm long, light green, receptive surface slightly convex, turned frontwards. Rostellum 1.3-1.4 mm long, whitish; mid-lobe triangular, fleshy, completely placed between the anther loci, $0.9 \mathrm{~mm}$ high; apex rounded to acute, curved frontwards; side-lobes sulcate, slightly convergent towards apices, $0.9 \times 0.35 \mathrm{~mm}$.
Distribution-Restricted to the southern region of the Espinhaço Range in Quadrilatero Ferrífero (Dorr 1969) in central Minas Gerais State. The species is currently known from only three localities: Serra do Itacolomi, Serra do Caraça, and the region between Ouro Branco and Ouro Preto. In Serra do Itacolomi it is known from a single, small population. In Serra do Caraça, the origin of most collections, it has been collected only at high altitudes near the summits of Pico do Sol and Pico do Inficcionado.

Habitat, Ecology, and Phenology-Habenaria quadriferricola grows between 1,600-1,900 $\mathrm{m}$ a. s. 1., in seasonally wet, high altitude fields (campo de altitude), over shallow, dark, sandy-clay soils, usually associated with rock outcrops. Flowering can begin in January, but is concentrated from February to March, with its peak at the end of the rainy season (Table 1). High altitude fields are less affected by fire, and the flowering of $H$. quadriferricola occurs regardless of the fire regime, it being one of the few species of the genus from a grassland habitat in which most collections are from areas not previously burned. Other Habenaria species, such as $H$. cf. paulensis Porsch, H. caldensis Kraenzl., and $H$. imbricata Lindl. occur in the same areas and flower at the same time.

Etymology - A reference to the Quadrilatero Ferrifero region. Conservation Status-Based on the World Conservation Union Red List Categories and Criteria (IUCN 2001), the new taxon can be tentatively classified as endangered (EN), due to its limited geographic range and small number of known populations [B1ab(iii)+2ab(iii)].

Notes-Based on known collections of the species, $H$. quadriferricola was first collected by R. C. Mota in Serra do Caraça in 2001. Specimens of this species were identified as indeterminate in several herbaria and were recorded as Habenaria sp. in a survey of the genus Habenaria in the Itacolomi State Park (Batista et al. 2004).

Habenaria quadriferricola is similar to H. hippocrepica in its vegetative and floral morphology, although $H$. quadriferricola has longer lateral sepal arista $(0.4-0.8 \mathrm{~mm}$ long vs. 0-0.4 mm long in $H$. hippocrepica), shorter anterior petal segments (1.0-2.0 $\mathrm{mm}$ vs. $3.6-7.0 \mathrm{~mm}$ in H. hippocrepica), and shorter lateral lip segments $(1.8-4.0 \mathrm{~mm}$ vs. $4.0-7.6(-10.4) \mathrm{mm}$ in H. hippocrepica) (Figs. 5, 6A-C; Table 2). The short anterior petal segment (0.2-0.4 times as long as the posterior segment) and short lateral lip segments $(0.4-0.6(-0.9)$ times as long as the median segment) distinguish $H$. quadriferricola not only from $H$. hippocrepica, but also from other species with slender plants, linear leaves, and small flowers, such as $H$. ayangannensis, $H$. canastrensis, $H$. ludibundiciliata, H. psammophila, H. pseudoculicina, H. subfiliformis, H. reflexicalcar, and $H$. espinhacensis. In all of these species, the anterior petal segment and lateral lip segments are approximately the same length or longer than the posterior petal segment and median lip segment, respectively.

Based on the similarities between $H$. quadriferricola and $H$. hippocrepica, we considered the hypothesis that $H$. quadriferricola could represent an infraspecific taxon of $H$. hippocrepica; however, considering that the morphological differences between them are constant and there is no overlapping of their geographical distributions, they are treated here as distinct species.

Additional Specimens Examined - BRAZIL. Minas Gerais: Ouro Preto, Parque Estadual do Itacolomi, Morro do itacolomi, platôs na base do pico, 15 Feb 2003 (fl), J. A. N. Batista et al. 1384 (CEN); Catas Altas, Serra do Caraça, trilha para o Pico do Inficcionado, 22 Feb 2006 (fl), J. A. N. Batista \& 


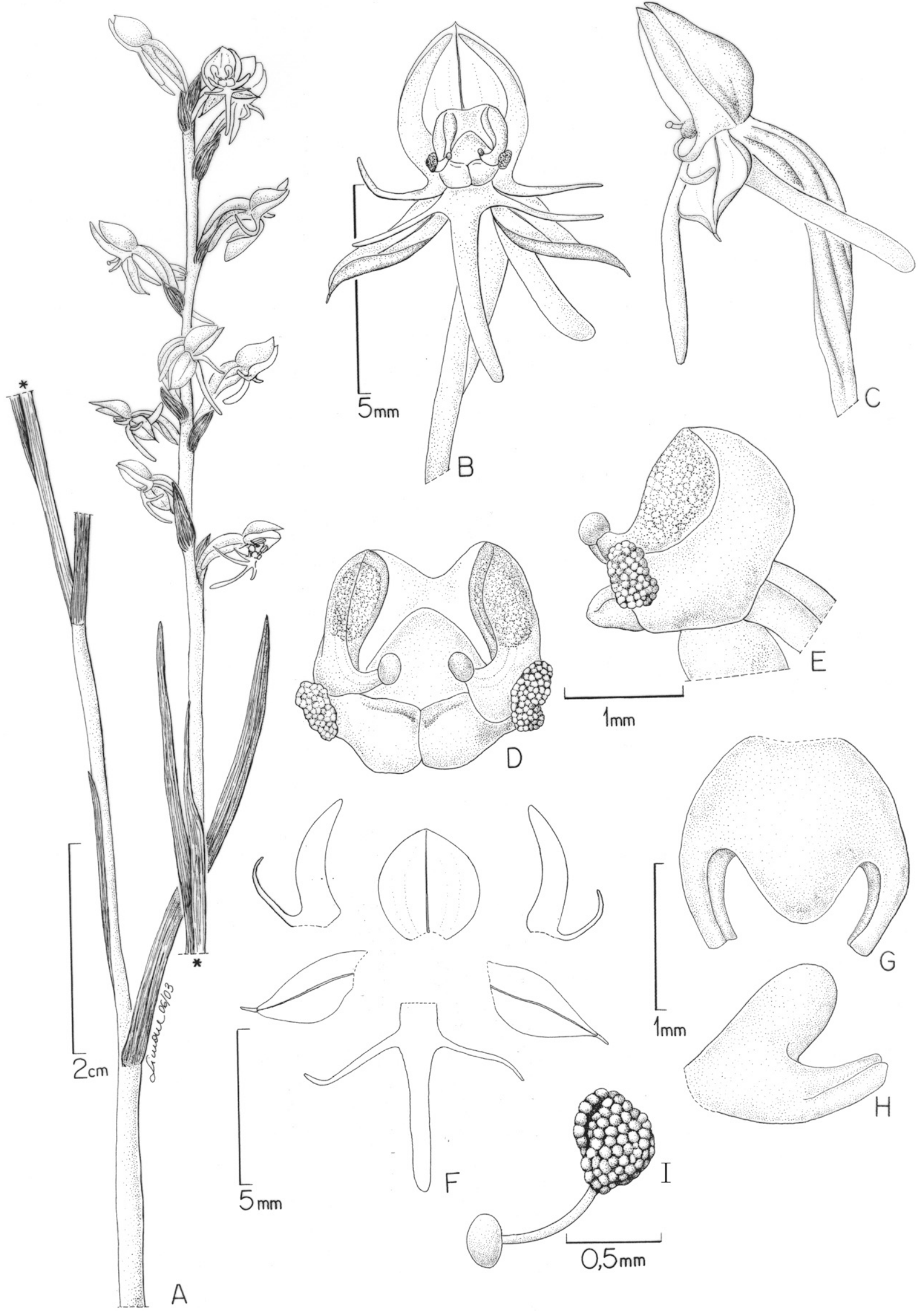

Fig. 5. Habenaria quadriferricola. A. Habit. B. Flower, front view. C. Flower, lateral view. D. Gynostemium, front view. E. Gynostemium, lateral view. F. Dissected perianth. G. Rostellum, upper view. H. Rostellum, lateral view. I. Hemipollinarium. All based on Batista et al. 1384. Drawn by Simone C. Souza e Silva. 


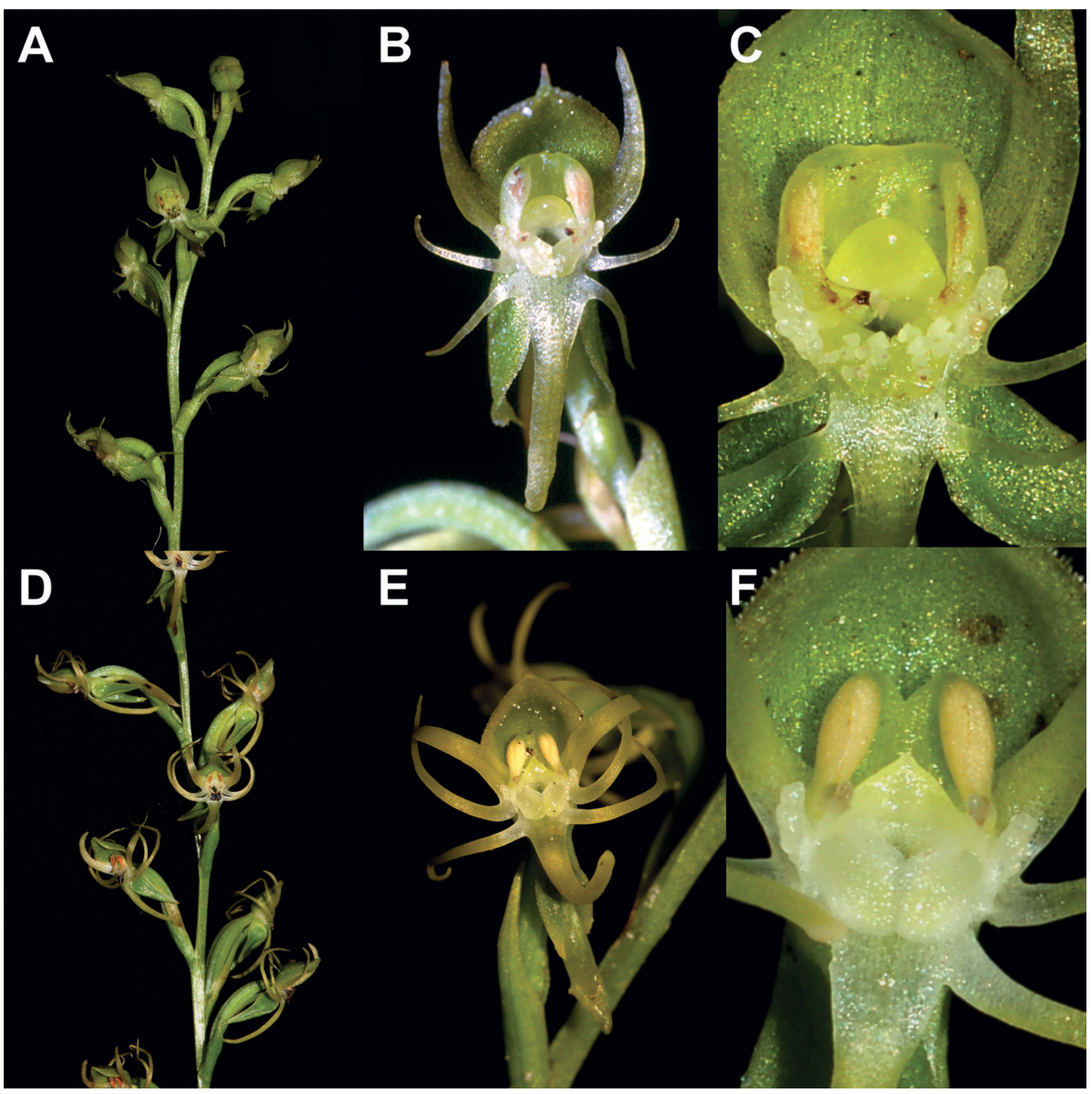

FIG. 6. Habenaria quadriferricola. A. Inflorescence. B. Flower. C. Gynostemium. Habenaria espinhacensis. D. Inflorescence. E. Flower. F. Gynostemium. A and C from Batista 2635; B from Batista et al. 1384. D from Batista et al. 2822 (Grão Mogol); E from Batista 3202 (Serra do Cipó); F from Batista et al. 3141 (Diamantina). All photographs by João A. N. Batista.

R. C. Mota 1619 (BHCB); Ouro Preto, Parque Estadual do Itacolomi, platôs na base do pico, próximo a Lagoa seca, $20^{\circ} 25^{\prime} \mathrm{S}, 43^{\circ} 29^{\prime} \mathrm{W}, 1,612 \mathrm{~m}$, 6 Mar 2008 (fl), J. A. N. Batista 2635 (BHCB); Catas Altas, Serra do Caraça, subida para o Pico do Sol, 20 $06^{\prime} \mathrm{S}, 43^{\circ} 27^{\prime} \mathrm{W}, 1,724 \mathrm{~m}, 21$ Mar 2009 (fl), B. M. Carvalho 34 (BHCB); Catas Altas, Santuário da Serra do Caraça, trilha para o Pico do Sol, 19 Jan 2004 (fl), L. Mickeliunas \& E. R. Pansarin 43 (CEN, UEC); Catas Altas, Serra do Caraça, 17 Feb 2001 (fl), R. C. Mota 1212 (BHCB); Catas Altas, Serra do Caraça, 18 Feb 2001 (fl), R. C. Mota 1222 (BHCB, CEN); Catas Altas, Serra do Caraça, Pico do Inficcionado, $20^{\circ} 08^{\prime} \mathrm{S}, 43^{\circ} 27^{\prime} \mathrm{W}, 1,900 \mathrm{~m}, 16 \mathrm{Feb} 2005$ (fl), R. C. Mota 2779 (BHCB); Catas Altas, Serra do Caraça, 1,800 m, caminho do Pico do Sol, 20 Mar 2005 (fl), R. C. Mota 2806 (BHCB); Catas Altas, Serra do Caraça, 1,850 m, Inficcionado, 20 Mar 2005 (fl), R. C. Mota 2815 (BHCB); Catas Altas, Serra do Caraça, subida do Pico do Inficcionado, 27 Mar 2007 (fl), R. C. Mota
3565 (BHCB); estrada Ouro Branco/Ouro Preto, Feb 2002 (fl), E. R. Pansarin E L. Mickeliunas 913 (BHCB, CEN, UEC).

Habenaria espinhacensis J. A. N. Bat. \& A. A. Vale, sp. nov.TYPE: BRAZIL. Minas Gerais: Grão Mogol, cerca de 1 km após a ponte sobre o Rio Itacambiruçu, na estrada Grão Mogol-Cristália, 16³5'37.9'S, 4253'41.1'W, 665 m, 4 Mar 2009 (fl), J. A. N. Batista, B. M. Carvalho E F. L. Baptista 2822 (holotype: BHCB; isotypes: CEN, HUEFS, MBM, $\mathrm{RB}, \mathrm{SP})$.

Similar to $H$. hippocrepica, but distinct by its more lax inflorescence ((0.7-)0.9-1.4(-1.8) flowers /cm of inflorescence), 
longer pedicellate ovary ((8-)11-14 mm), longer spur (9$12 \mathrm{~mm})$, anterior petal segment (1.2-)1.5-2 times longer than the posterior segment, shorter connective (0.5-0.9 $\mathrm{mm}$ long), rostellum side-lobes parallel to each other, and rostellum mid-lobe with an acute to subacute apex.

Terrestrial caulescent herb. Tuberoid and roots not examined. Stem erect, (12-)19-53(-68) cm, including the inflorescence, $0.9-1.8 \mathrm{~mm}$ wide. Leaves $4-8$, base sheathing, sheath closed, blade partially adpressed to the stem or ascending, narrowly lanceolate to lanceolate, channeled, largest at the lower half or center of the stem, 5.0-13.0 × 0.2-0.6 cm, membranaceous, acuminate. Inflorescence (2.5-)6.0-23.0(-30.0) cm, few to many flowered, lax, spiral, (0.7-)0.9-1.4(-1.8) flowers for $\mathrm{cm}$ of inflorescence; bracts ovate, usually shorter than the pedicellate ovary, 5-14 × 3-4 mm, caudate. Flowers (2-)4$24(-38)$, resupinate, glabrous, green; pedicellate ovary ascending, (8-)11-14 mm long; ovary slightly arched, (6-)8-11 mm long, pedicel 1.6-3.6 mm long. Sepals green, margins whitish, apex acute, arista $0.0-0.6 \mathrm{~mm}$; dorsal sepal concave, ovate when flattened, 3-6 × 2-5 mm; lateral sepals obliquely lanceovate or obliquely lanceolate, deflexed, 5-7 × 2-4 mm, acute. Petals bipartite, green, base whitish; posterior segment lanceolate, falcate, $4.8-6.7 \times 0.7-1.2 \mathrm{~mm}$, free from the dorsal sepal, acute; anterior segment linear-filiform, erect, inserted at the base of the posterior segment, 7.0-12.0 mm, (1.2-)1.5-2 times as long as the posterior segment. Lip tripartite, green, base whitish; undivided basal part short, $0.4-0.8 \times 0.8-1.4 \mathrm{~mm}$; lateral segments linear-filiform, base perpendicular to the median segment, apices erect, 6-11 mm, (1.1-)1.3-1.6 times as long as the median segment; median segment linear, 5.5-9.0 $\times$ 0.6-1.0 $\mathrm{mm}$, acute; spur partially covered by the bracts or free, slightly shorter than pedicellate ovary, 7-12 mm long, fusiform, with the widest part shifted to the distal part, (0.7-)1.0-1.5 mm wide, green. Gynostemium erect, 1.5-3.0 mm high; connective emarginate, $0.5-0.9 \mathrm{~mm}$ long, green; lateral appendages (auricles) fleshy, verrucose, 0.2-0.5 × 0.3-0.4 mm. Anther bilocular, loculi parallel, 0.6-1.2 mm high, canals 0.7$1.0 \mathrm{~mm}$ long, hemipollinaria separate; viscidia ellipsoid, $0.1-$ $0.2 \times 0.1-0.2 \mathrm{~mm}$, spaced $0.8 \mathrm{~mm}$ from each other; caudicles 0.8-1.3 mm long. Stigmatophores (stigma lobes) 2, closely parallel, 1.8-2.0 mm long, green, receptive surface slightly convex, turned frontwards, $0.6-0.9 \times 0.3-0.8 \mathrm{~mm}$, apex truncate, inner margin thickened. Rostellum 1.5-1.7 mm long, green; mid-lobe erect, triangular, fleshy, acute to subacute, completely placed between the anther loci, 0.6-0.8 mm long, 0.8$1.1 \mathrm{~mm}$ high; side-lobes parallel throughout, $0.6-0.8 \mathrm{~mm}$ long, base $0.5-0.6 \mathrm{~mm}$ wide, apex $0.2-0.3 \mathrm{~mm}$ wide.

Distribution-Habenaria espinhacensis is known from the Espinhaço Range in Minas Gerais and Bahia; in Minas Gerais, it occurs in the central and northern regions of that range. Collections extend from Serra do Cipó to Serra Nova at Rio Pardo de Minas. In Bahia, it is known from only a single record from Barra da Estiva, in the Espinhaço Range of that state.

Habitat, Ecology, and Phenology-Habenaria espinhacensis grows between 600 and 1,300 $\mathrm{m}$ in dry or seasonally wet grasslands (campo limpo seco or campo limpo estacionalmente úmido), on sandy or sandy-clay, shallow soils, and is frequently associated with rock outcrops in campo rupestre areas. In some instances, the species was found growing on small patches of soil on quartzite outcrops among rupicolous species of Barbacenia Vand. (Velloziaceae). Flowering occurs from January to May, from the peak of the rainy season until its end (Table 1). The only known record of this species from
Bahia was collected with flowers in July, which corresponds to the end of the rainy season in northeastern Brazil. Other Habenaria and orchid species, such as $H$. pubidactyla subsp. pubidactyla, H. guilleminii, and Cleistes bella Rchb.f. \& Warm., occur in the same areas and flower at about the same time. Some collections were made by the authors in areas that had not burned, although others were from previously burned areas (including the large population used to typify the species). The flowering of $H$. espinhacensis seems to be less influenced by fire than the other Habenaria species described here.

Etymology - A reference to the Espinhaço Range.

Conservation Status-Based on the World Conservation Union Red List Categories and Criteria (IUCN 2001), the new taxon can be tentatively classified as of least concern (LC). Habenaria espinhacensis has the widest distribution range among the new species described here, being known from several localities with large populations - some of which are located inside federal or state protected areas.

Illustration - Barros and Pinheiro (2004, Fig. 3F, line drawing of a dissected perianth, identified as $H$. aff. ayangannensis).

Notes-This is one of several new species of Habenaria that were first collected after the 1960s when systematic botanical explorations of the Espinhaço Range were initiated by H. S. Irwin (later followed by botanists from several universities and institutions from São Paulo State); it had remained overlooked until now. Based on known collections, H. espinhacensis apparently was first collected by Howard Irwin in 1969 near Diamantina, Minas Gerais. Duplicates of this collection in the UB, HB, and NY herbaria were identified at different times by Pabst as $H$. gracilis Lindl, $H$. cf. setacea Lindl. var. depauperata Cogn. (a synonym of $H$. ayangannensis) (Batista et al. 2011a), and as H. culicina Rchb.f. \& Warm. More recently, Barros and Pinheiro (2004) identified specimens of this species as $H$. aff. ayangannensis; other collections were indeterminate in several herbaria.

Habenaria espinhacensis can be distinguished from the other species described here (as well as other morphologically similar species) such as $H$. ayangannensis, $H$. canastrensis, $H$. culicina, H. ludibundiciliata, H. psammophila, and H. pseudoculicina) by a combination of characters that include its spiral, lax inflorescence ((0.7-)0.9-1.4(-1.8) flowers/cm of inflorescence), pedicellate ovary (8-)12-14 mm long, spur 9$12 \mathrm{~mm}$ long, perianth glabrous, lateral sepal arista $0.2-0.6 \mathrm{~mm}$ long, anterior petal segment (1.2-)1.5-2 times longer than the posterior segment, connective $0.5-0.9 \mathrm{~mm}$ long, hemipollinaria separated, rostellum arms parallel to each other, and rostellum mid-lobe with an acute to subacute apex (Figs. 6D-F, 7).

Some morphological differences were observed between $H$. espinhacensis populations in the central and northern regions of the Espinhaço Range. Specimens from the northern region (Grão Mogol, Serra do Cabral, and Rio Pardo de Minas) were usually taller ((19-)30-55(-68) cm), with leaves narrower and more widely distributed along the stem, and more flowers ((3-)11-28(-38) flowers), while specimens from the central and southern regions of the Espinhaço Range were smaller ((12-)15-25(-29) cm), had leaves slightly wider and more concentrated in the lower part of the stem, and fewer flowers (2-18). Molecular phylogenetic analyses likewise indicated a geographic separation between the southern and northern populations of this species. There were no significant differences in the overall sizes and morphologies of flowers among different populations of the species, however. Because 

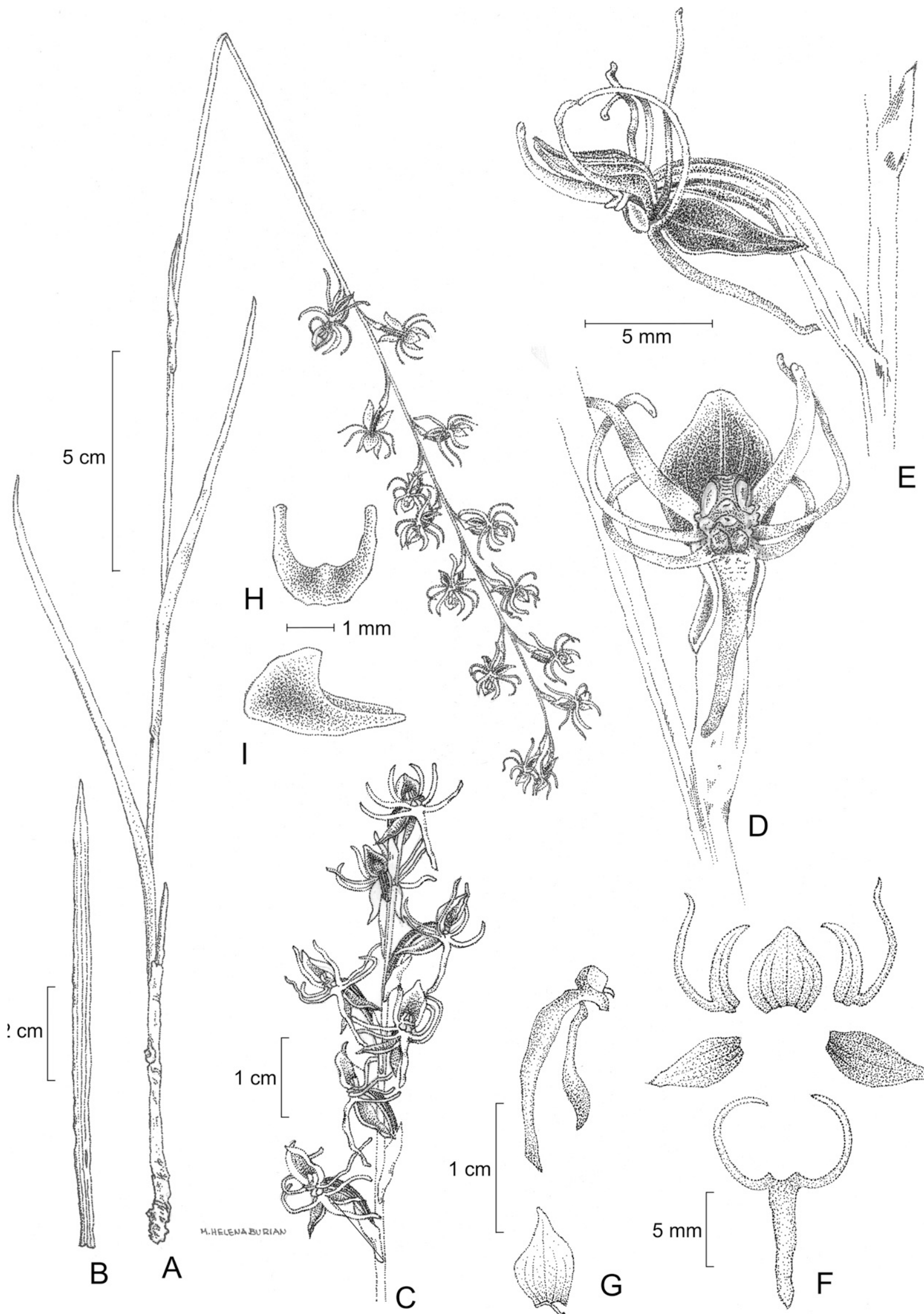

FIG. 7. Habenaria espinhacensis. A. Habit. B. Leaf. C. Inflorescence. D. Flower, front view. E. Flower, lateral view. F. Dissected perianth. G. Bract, pedicellate ovary, spur and gynostemium, lateral view. H. Rostellum, upper view. I. Rostellum, lateral view. All based on Batista et al. 2822. Drawn by Maria Helena Burian. 
there is considerable overlap of the characters described above, separating these two patterns does not appear to be justified (and would be morphologically impractical).

Additional Specimens Examined-BRAZIL. Bahia: Barra da Estiva, Morro da Antena, $13^{\circ} 41^{\prime} \mathrm{S}, 41^{\circ} 16^{\prime} \mathrm{W}, 1,200-1,400 \mathrm{~m}, 16 \mathrm{Jul} 2001$ (fl), $V$. C. Souza et al. 26103 (ESA). Minas Gerais: Joaquim Felício, Serra do Cabral, $17^{\circ} 41^{\prime} \mathrm{S}, 44^{\circ} 11^{\prime} \mathrm{W}, 993 \mathrm{~m}, 3$ Mar 2009 (fl), J. A. N. Batista et al. 2814 (BHCB); Grão Mogol, Parque Estadual Grão Mogol, Serra de Grão Mogol, trilha da tropa, em direção ao cume da serra, $16^{\circ} 33^{\prime} \mathrm{S}, 42^{\circ} 53^{\prime} \mathrm{W}$, 989 m, 5 Mar 2009 (fl), J. A. N. Batista et al. 2827 (BHCB); Diamantina, afloramento rochoso a esquerda da MG-220, sentido Diamantina para Conselheiro Mata, cerca de $20 \mathrm{~km}$ do entroncamento com a BR-367, $18^{\circ} 17^{\prime} 52^{\prime \prime} \mathrm{S}, 43^{\circ} 50^{\prime} 17.6^{\prime \prime} \mathrm{W}, 1,232 \mathrm{~m}, 6$ Jan 2011 (fl), J. A. N. Batista et al. 3141 (BHCB); Santana do Riacho, Serra do Cipó, estrada entre Santana do Riacho e o vilarejo de Rio de Pedras, trilha de subida para o alto da serra a partir do sítio do João Carrinho, $1^{\circ} 03^{\prime} 0.49^{\prime \prime} \mathrm{S}, 43^{\circ} 44^{\prime} 14.08^{\prime \prime} \mathrm{W}$, 1,134 m, 7 Feb 2012 (fl), J. A. N. Batista 3202 (BHCB); Rio Pardo de Minas, Parque Estadual da Serra Nova, Escorrega, 23 Mar 2012 (fl), J. A. N. Batista et al. 3227 (BHCB); Santana do Riacho, Serra do Cipó, Parque Nacional da Serra do Cipó, estrada ligando Capela de São José a Santana do Riacho, subida do João Carrinho, $19^{\circ} 02^{\prime} 55^{\prime \prime} \mathrm{S}, 43^{\circ} 44^{\prime} 14^{\prime \prime} \mathrm{W}, 1,000 \mathrm{~m}$, 25 Feb 2009 (fl), C. N. Fraga et al. 2386 (RB); Gouveia, BR-259, subida da Serra do Espinhaço, 850-1,000 m, 23 Feb 1975 (fl), G. Hatschbach et al. 36427 (MBM, NY); Serra do Espinhaço, $12 \mathrm{~km} \mathrm{NE}$ of Diamantina, road to Medanha, 1300 m, 27 Jan 1969 (fl), H. S. Irwin et al. 22698 (HB, NY, UB); Grão Mogol, próxima da saída na entrada para Francisco Sá, 1000 m, 7 Jan 1986, C. Kameyama et al. in CFCR 9015 (SP, SPF); Grão Mogol, estrada para Cristália, 16 $6^{\circ} 3^{\prime} 34^{\prime \prime}$ S, 42 $53^{\prime} 23^{\prime \prime} \mathrm{W}, 829 \mathrm{~m}, 15$ May 2008 (fl, fr), C. A. N. Martins et al. 37 (BHCB); Santana do Riacho, estrada Lapinha - Congonhas do Norte, entre a fazenda Cacheira e a RPPN Ermo Gerais, $19^{\circ} 02^{\prime} \mathrm{S}, 43^{\circ} 42^{\prime} \mathrm{W}, 1,250 \mathrm{~m}, 29$ Jan 2008 (fl), A. Rapini et al. 1646 (HUEFS); Rio Pardo de Minas, Parque Estadual da Serra Nova, inicio da trilha areal, 15 $5^{\circ} 39^{\prime} 14^{\prime \prime} \mathrm{S}, 42^{\circ} 43^{\prime} 53^{\prime \prime} \mathrm{W}$, 20 Mar 2012 (fl), M. J. R. Rocha et al. 385 (BHCB); Rio Pardo de Minas, Parque Estadual da Serra Nova, no córrego após a casa do IEF, $15^{\circ} 35^{\prime} 32^{\prime \prime} \mathrm{S}, 42^{\circ} 45^{\prime} 98^{\prime \prime} \mathrm{W}, 25$ Mar 2012 (fl), M. J. R. Rocha et al. 579 (BHCB); Grão Mogol, trilha da tropa, 16 ${ }^{\circ} 32^{\prime} 29^{\prime \prime}$ S, $42^{\circ} 55^{\prime}$ 16"W, 1,600 m, 4 Feb 2007 (fl), A. K. A. Santos et al. 995 (HUEFS); Grão Mogol, afloramento na estrada de Cristália, próximo a ponte da Cachoeira do Véu, $16^{\circ} 30^{\prime} \mathrm{S}, 42^{\circ} 41^{\prime} \mathrm{W}, 807 \mathrm{~m}, 22 \mathrm{Feb} 2004$ (fl), C. van den Berg 1377 (HUEFS); Santana do Riacho, Ermo das Geraes, 20 Jan 2002 (fl), P. L. Viana s. n. (BHCB 69741); Santana do Riacho, Serra do Cipó, acesso pela Fazenda Inhame, trilha do João Carrinho, $19^{\circ} 02^{\prime} 55^{\prime \prime} \mathrm{S}, 43^{\circ} 44^{\prime}$ $14^{\prime \prime} \mathrm{W}, 1,000 \mathrm{~m}, 25 \mathrm{Feb} 2009$ (fl), D. C. Zappi et al. 1566 (RB).

AcKNOWLEDGments. The authors would like to thank the curators and staff of the following herbaria for loans and/or for support while visiting their collections: BHCB, CEN, ESA, HB, HBG, HUEFS, K, MBM, NY, P, RB, SP, SPF, UEC, and UB. We are also grateful to SISBIO and IEF Minas Gerais for the scientific collection permits, Tarciso Filgueiras for corrections and suggestions concerning the Latin names, and Maria Helena Burian and Simone C. Souza e Silva for the line drawings. We also greatly appreciate the careful reading, corrections and suggestions provided by two anonymous reviewers. JANB acknowledges financial support from the Fundação Grupo Boticário de Proteção à Natureza, the Fundação de Amparo a Pesquisa do Estado de Minas Gerais (FAPEMIG), and the Conselho Nacional de Desenvolvimento Científico e Tecnológico (CNPq). CvdB and JANB also acknowledge scholarships received from $\mathrm{CNPq}(\mathrm{Pq}-1 \mathrm{~B}$ and $\mathrm{Pq}-2)$.

\section{Literature Cited}

Azevedo, C. O. and C. van den Berg. 2007. Análise comparativa de áreas de campos rupestres da Cadeia do Espinhaço (Bahia e Minas Gerais, Brasil) baseada em espécies de Orchidaceae. Sitientibus, série Ciências Biológicas 7: 199-210.

Barros, F. 1987. Orchidaceae. Pp. 125-130 in Flora da Serra do Cipó, Minas Gerais: caracterização e lista das espécies eds. A. M. Giulietti, N. L. Menezes, J. R. Pirani, M. Meguro, and M. G. L. Wanderley. Boletim de Botânica da Universidade São Paulo 9(1).

Barros, F. and F. Pinheiro. 2004. Flora de Grão-Mogol, Minas Gerais: Orchidaceae. Boletim de Botânica da Universidade de São Paulo 22: 361-383.

Barros, F., F. Vinhos, V. T. Rodrigues, F. F. V. A. Barberena, C. N. Fraga, E. M. Pessoa, W. Forster, L. Menini Neto, S. G. Furtado, C. Nardy,
C. O. Azevedo, and L. R. S. Guimarães. 2015. Orchidaceae in Lista de Espécies da Flora do Brasil. Jardim Botânico do Rio de Janeiro, Rio de Janeiro. Available at: http://floradobrasil.jbrj.gov.br/jabot/ floradobrasil/FB11639 (accessed: 05 May 2015).

Batista, J. A. N. and L. B. Bianchetti. 2006. The Brazilian Habenaria (Orchidaceae) with hairy segments. Sitientibus, série Ciências Biológicas 6: 9-23.

Batista, J. A. N., L. B. Bianchetti, R. E. Nogueira, K. F. Pellizzaro, and F. E. Ferreira. 2004. The genus Habenaria (Orchidaceae) in the Itacolomi state park, Minas Gerais, Brazil. Sitientibus, série Ciências Biológicas 4: $25-36$.

Batista, J. A. N., L. B. Bianchetti, and Z. J. G. Miranda. 2008a. Two new species of Habenaria (Orchidaceae) from the Brazilian cerrado and campo rupestre. Kew Bulletin 63: 449-456.

Batista, J. A. N., R. C. Mota, N. L. Abreu, and L. Menini Neto. 2008 b. Habenaria pseudoglaucophylla (Orchidaceae), a new species from Minas Gerais, Brazil. Novon 18: 409-414.

Batista, J. A. N., L. B. Bianchetti, R. González-Tamayo, X. M. C. Figueroa, and P. J. Cribb. 2011a. A synopsis of new world Habenaria (Orchidaceae) I. Harvard Papers in Botany 16: 1-47.

Batista, J. A. N., L. B. Bianchetti, R. González-Tamayo, X. M. C. Figueroa, and P. J. Cribb. 2011b. A synopsis of new world Habenaria (Orchidaceae) II. Harvard Papers in Botany 16: 233-273.

Batista, J. A. N., K. S. Borges, M. W. Faria, K. Proite, A. J. Ramalho, G. A. Salazar, and C. van den Berg. 2013. Molecular phylogenetics of the species-rich genus Habenaria (Orchidaceae) in the New World based on nuclear and plastid DNA sequences. Molecular Phylogenetics and Evolution 67: 95-109.

Bonfield, J. K., K. F. Smith, and R. Staden. 1995. A new DNA sequence assembly program. Nucleic Acids Research 24: 4992-4999.

Chase, M. W., R. S. Cowan, P. M. Hollingsworth, C. van den Berg, S. Madriñán, G. Petersen, O. Seberg, T. Jørgsensen, K. M. Cameron, M. Carine, N. Pedersen, T. A. J. Hedderson, F. Conrad, G. A. Salazar, J. E. Richardson, M. L. Hollingsworth, T. G. Barraclough, L. Kelly, and M. Wilkinson. 2007. A proposal for a standardized protocol to barcode all land plants. Taxon 56: 295-299.

Conceição, A. A. and J. R. Pirani. 2007. Diversidade em quatro áreas de campos rupestres na Chapada Diamantina, Bahia, Brasil: espécies distintas, mas riquezas similares. Rodriguésia 58: 193-206.

Costa, F. N., M. Trovó, and P. T. Sano. 2008. Eriocaulaceae na Cadeia do Espinhaço: Riqueza, endemismo e ameaças. Megadiversidade 4: $89-97$.

Dorr, J. V. N. 1969. Physiographic, stratigraphic, and structural development of the Quadrilatero Ferrifero, Minas Gerais, Brazil. U.S. Geological Survey Professional Paper 641-A: 1-110.

Dutra, V. F., F. C. P. Garcia, H. C. Lima, and L. P. Queiroz. 2008. Diversidade florística de Leguminosae Adans. em áreas de campos rupestres. Megadiversidade 4: 145-153.

Echternacht, L., M. Trovó, C. T. Oliveira, and J. R. Pirani. 2011. Areas of endemism in the Espinhaço Range in Minas Gerais, Brazil. Flora 206: 782-791.

Edgar, R. C. 2004. MUSCLE: Multiple sequence alignment with high accuracy and high throughput. Nucleic Acids Research 32: 1792-1797.

Erixon, P., B. Svennblad, T. Britton, and B. Oxelman. 2003. Reliability of Bayesian posterior probabilities and bootstrap frequencies in phylogenetics. Systematic Biology 52: 665-673.

Felsenstein, J. 1985. Confidence limits on phylogenies: An approach using the bootstrap. Evolution 39: 783-791.

Fitch, W. M. 1971. Toward defining the course of evolution: Minimum change for a specific tree topology. Systematic Zoology 20: 406-416.

Giulietti, A. M. and J. R. Pirani. 1988. Patterns of geographic distribution of some plant species from the Espinhaço Range, Minas Gerais and Bahia, Brazil. Pp. 39-69 in Proceedings of a workshop on Neotropical distribution patterns, eds. P. E. Vanzolini and W. R. Heyer. Rio de Janeiro: Academia Brasileira de Ciências.

Govaerts, R., P. Bernet, K. Kratochvil, G. Gerlach, G. Carr, P. Alrich, A. M. Pridgeon, J. Pfahl, M. A. Campacci, D. H. Baptista, H. Tigges, J. Shaw, P. Cribb, A. George, K. Kreuz, and J. Wood. 2015. World Checklist of Orchidaceae. Richmond, U. K.: The Board of Trustees of the Royal Botanic Gardens, Kew. Available at: http://apps.kew .org/wcsp/ (accessed: 27 April 2015).

IUCN. 2001. IUCN Red List Categories and Criteria, Version 3.1. Gland: IUCN Species Survival Commission.

Jones, D. L. 1993. Native orchids of Australia. Auckland: Reed Books.

Kress, W. J., L. M. Prince, and K. J. Williams. 2002. The phylogeny and a new classification of the gingers (Zingiberaceae): Evidence from molecular data. American Journal of Botany 89: 1682-1696. 
Lista de Espécies da Flora do Brasil. 2015. Jardim Botânico do Rio de Janeiro, Rio de Janeiro. Available at: http://floradobrasil.jbrj.gov.br/ (accessed: 31 Mar 2015).

Miller, M. A., W. Pfeiffer, and T. Schwartz. 2010. Creating the CIPRES Science Gateway for inference of large phylogenetic trees. Pp. 1-8 in Proceedings of the Gateway Computing Environments Workshop (GCE). New Orleans: GCE.

Mota, R. C. 2006. Orchidaceae na Serra do Caraça, Minas Gerais: Levantamento florístico com ênfase no estudo taxonômico da subfamília Epidendroideae. M. S. thesis. Belo Horizonte, Minas Gerais: Universidade Federal de Minas Gerais.

Munhoz, A. C. D. 2007. Floristica e sistemática do gênero Habenaria (Orchidaceae) na Serra do Cipó. M. S. Thesis. Belo Horizonte, Minas Gerais: Universidade Federal de Minas Gerais.

Nylander, J. A. A. 2004. MrModeltest v2. Program distributed by the author. Uppsala: Evolutionary Biology Centre, Uppsala University.

Pridgeon, A. M., P. J. Cribb, M. W. Chase, and F. N. Rasmussen. 2001. Genera Orchidacearum. Orchidoideae (Part 1) vol. 2. New York: Oxford University Press.

Rapini, A., R. Mello-Silva, and M. L. Kawasaki. 2002. Richness and endemism in Asclepiadoideae (Apocynaceae) from the Espinhaço Range of Minas Gerais, Brazil - a conservationist view. Biodiversity and Conservation 11: 1733-1746.

Rapini, A., P. L. Ribeiro, S. Lambert, and J. R. Pirani. 2008. A flora dos campos rupestres da Cadeia do Espinhaço. Megadiversidade 4: 15-23.

Ronquist, F., J. P. Huelsenbeck, and P. van der Mark. 2005. MrBayes: Bayesian Inference of Phylogeny. Program distributed by the authors. Available from: http://mrbayes.sourceforge.net/index.php.

Salino, A. and T. E. Almeida. 2008. Diversidade e conservação das pteridófitas na Cadeia do Espinhaço, Brasil. Megadiversidade 4: 78-98.

Simpson, M. G. 2006. Plant systematics. Burlington, San Diego and London: Elsevier Academic Press.

Stearn, W. T. 1992. Botanical Latin. Ed. 4. Portland, Oregon: Timber Press.

Sun, Y., D. Z. Skinner, G. H. Liang, and S. H. Hulbert. 1994. Phylogenetic analysis of Sorghum and related taxa using internal transcribed spacers of nuclear ribosomal DNA. Theoretical and Applied Genetics 89: 26-32.

Swofford, D. L. 2002. PAUP* Phylogenetic analysis using parsimony (*and other methods). Version 4. Sunderland: Sinauer Associates.

Tamura, K., J. Dudley, M. Nei, and S. Kumar. 2007. MEGA4: Molecular evolutionary genetics analysis (MEGA) software version 4.0. Molecular Biology and Evolution 24: 1596-1599.

Thiers, B. 2015 [continuously updated]. Index Herbariorum: A global directory of public herbaria and associated staff. New York Botanical Garden's Virtual Herbarium. Available at http://sweetgum .nybg.org/science/ih/. (accessed: 30 Jul 2015).
Toscano-de-Brito, A. L. V. 1995. Orchidaceae. Pp. 725-767 in Flora of the Pico das Almas: Chapada Diamantina, Bahia, Brazil ed. B. L. Stannard. Kew, Royal Botanic Gardens.

Vasconcelos, M. F. 2011. O que são campos rupestres e campos de altitude nos topos de montanha do Leste do Brasil? Revista Brasileira de Botanica. Brazilian Journal of Botany 34: 241-246.

Versieux, L. M. and T. Wendt. 2007. Bromeliaceae diversity and conservation in Minas Gerais state, Brazil. Biodiversity and Conservation 6: 2989-3009.

Versieux, L. M., T. Wendt, R. B. Louzada, and M. G. L. Wanderley. 2008 Bromeliaceae da Cadeia do Espinhaço. Megadiversidade 4: 98-110.

Whitten, W. M., N. H. Williams, and M. W. Chase. 2000. Subtribal and generic relationships of Maxillarieae (Orchidaceae) with emphasis on Stanhopeinae: Combined molecular evidence. American Journal of Botany 87: 1842-1856.

Zappi, D. C., E. Lucas, B. L. Stannard, E. N. Lughadha, J. R. Pirani, L. P. Queiroz, S. Atkins, D. J. N. Hind, A. M. Giulietti, R. M. Harley, and A. M. Carvalho. 2003. Lista das plantas vasculares de Catolés, Chapada Diamantina, Bahia, Brasil. Boletim de Botânica da Universidade São Paulo 21: 345-398.

ApPENDIX 1. Voucher information for species sampled from the Espinhacenses clade and GenBank accession numbers for DNA sequences. Information is as follows: species name, voucher information and GenBank accession numbers for ITS and matK. An en-dash denotes missing data. Other sequences used for the phylogenetic analyses are the same previously used to infer phylogenetic relationships of New World Habenaria and voucher information, geographic origins, and GenBank accession numbers can be found in Batista et al. (2013).

Habenaria reflexicalcar, BRAZIL, Minas Gerais, Santana do Riacho, Serra do Cipó, J. A. N. Batista 1744 (BHCB), HM777700, HM777948; H. hippocrepica, BRAZIL, Minas Gerais, Diamantina, J. A. N. Batista 1948 (BHCB), HM777698, HM777946; Minas Gerais, Presidente Kubitschek, J. A. N. Batista 1920 (BHCB), KT831440, KT831445; Minas Gerais, Conceição do Mato Dentro, C. van den Berg 1356 (HUEFS), HM777697, -; H. quadriferricola, BRAZIL, Minas Gerais, Catas Altas, Serra do Caraça, J. A. N. Batista 1619 (BHCB), HM777699, HM777947; H. espinhacensis, BRAZIL, Minas Gerais, Joaquim Felício, Serra do Cabral, J. A. N. Batista 2814 (BHCB), HM777701, HM777949; Minas Gerais, Grão Mogol, J. A. N. Batista 2827 (BHCB), KT831441, KT831446; Minas Gerais, Diamantina, J. A. N. Batista 3141 (BHCB), KT831442, KT831447; Minas Gerais, Santana do Riacho, Serra do Cipó, J. A. N. Batista 3202 (BHCB), KT831443, KT831448; Minas Gerais, Rio Pardo de Minas, Serra Nova, J. A. N. Batista 3227 (BHCB), KT831444, -; 